Pablo Castillo, Andrés I. Nico, Juan A. Navas-Cortés, and Blanca B. Landa

Institute of Sustainable Agriculture (IAS), CSIC, Córdoba, Spain

\author{
Rafael M. Jiménez-Díaz \\ IAS-CSIC and University of Córdoba, Córdoba, Spain \\ Nicola Vovlas
Istituto per la Protezione delle Piante, C.N.R., Bari, Italy
}

\title{
Plant-Parasitic Nematodes Attacking Olive Trees and their Management
}

\section{Importance of Olives and Their Associated Nematodes}

Olive trees (Olea europaea (L.) subsp. europaea (L.)) were among the first fruit trees cultivated and are among the most ancient crops in the Mediterranean Basin (103). Cultivated olive trees can be distinguished from their wild relatives by larger fruits and higher oil content of the fleshy oil-containing mesocarp. The edible oil and fruit products of cultivated olive trees are prized worldwide. Botanical studies of pollen grains, stones, and wood from archaeological contexts indicate that the East Mediterranean (Israel) was the first area in which olive was domesticated (54). In the Mediterranean Basin, olive constitutes a complex of wild forms, weedy types, and cultivated varieties. Wild oleasters (Olea europaea (L.) subsp. sylvestris (Brot.)) occupy primary niches and occur in disturbed areas and in areas of abandoned cultivation (33). Cultivated olive is also grown extensively in the subtropical regions of Australia, southern Africa, and North and South America. More than $80 \%$ of 8 million hectares of olive grown worldwide in 2007 were located in Mediterranean countries, including North Africa. An additional $17 \%$ occur in the Middle East (Iraq, Iran, Jordan, and Syria), and less than $2 \%$ are found in the Americas (Argentina, Chile, Mexico, Peru, and the United States) (34). Olive crops are one of the most important sources of edible oil, and

Corresponding author: P. Castillo, Research Scientist, Institute of Sustainable Agriculture (IAS), Spanish National Research Council (CSIC), P.O. Box 4084, 14080 Córdoba, Spain

E-mail: pcastillo@ias.csic.es

doi:10.1094/PDIS-94-2-0148

(C) 2010 The American Phytopathological Society olive varieties are cultivated for oil extraction. Olive oil has many favorable nutritional properties; as a result, consumption of olive oil is increasing worldwide, extending the consumption area from the traditional one in the Mediterranean Basin (i.e., $77 \%$ of the world production area) to Australia, Canada, Japan, and the United States. Some olive varieties are specifically cultivated for direct consumption as table olives.

Olive trees serve as hosts to a large number of plant-parasitic nematodes, of which root-knot nematodes (Meloidogyne spp.), root-lesion nematodes (Pratylenchus spp.), spiral nematodes (Helicotylenchus spp.), and Mesocriconema xenoplax (Raski) Loof \& De Grisse, 1989 are widely distributed (Table 1) $(2,42,51,65,70,74)$. Conversely, limited distribution on olive has been reported for the citrus (Tylenchulus semipenetrans Cobb, 1913) and the cyst-forming (Heterodera mediterranea Vovlas, Inserra \& Stone, 1981) nematodes $(19,21,59)$. Of the endoparasitic nematodes (including Meloidogyne, Pratylenchus, Tylenchulus, and Heterodera), many are recognized as pathogenic to olive. The effects of parasitism by some nematodes on plant growth and yield result from disruption of the normal process of plant root growth and function (40). Water stress and nutrient deficiencies occur as the plant root system fails to adequately explore and exploit the soil due to plant parasitic nematode attacks. Damage to established olive orchards by nematode parasitism may not be clearly perceived because olive is an extremely vigorous plant able to thrive in relatively dry areas, which may obscure expression of symptoms from nematode attacks. However, modern olive production is based largely on the establishment of new high-input orchards intended to in- crease yields while reducing the time for investment recovery. This model, broadly adopted in new olive-producing areas of the Southern Hemisphere and the Mediterranean Basin, creates an environment conducive to diseases caused by or involving nematodes. In Argentina, for example, Meloidogyne javanica (Treub, 1885) Chitwood, 1949 was one of the main pathogens associated with a high incidence of "drying syndrome" in newly established olive orchards (75). Similarly, estimates of olive losses in the United States due to Meloidogyne spp. and T. semipenetrans ranged from 5 to $10 \%$ (44). Nematode damage to olive is particularly evident in nurseries, where optimum irrigation practices favor root proliferation and increased nematode population growth that subsequently impacts adult trees $(29,70)$.

The accurate and timely identification of plant-parasitic nematodes infecting crops is a prerequisite for designing effective management strategies. This is particularly relevant for olive trees because of the diversity of pathogenic nematode genera and species in several growing areas (Table 1). A reliable identification allows distinction between pathogenic and nonpathogenic nematodes and exclusion of species under quarantine or regulatory strategies. Identification of most nematodes is based on morphology and morphometric traits of adult females $(20,40)$, but the task is hindered by the need for experienced diagnosticians to assess the intraspecific variability of morphological traits. To illustrate this point, the main comparative diagnostic traits of Meloidogyne spp. attacking olives are summarized (Table 2). The last few years have seen the development of reliable diagnostic methods based on nucleic acid analyses, which have significantly improved and facilitated the routine identi- 
fication of Meloidogyne and Pratylenchus species (16). Polyphasic taxonomy, which assembles and assimilates all available information, may be a better strategy for delimiting taxa at all levels (e.g., combined use of internal transcribed spacer region sequences [ITS] of ribosomal DNA [rDNA], esterase phenotypes, and female perineal patterns; Fig. 1). This is especially valid for those Meloidogyne spp. that cannot be well resolved by phylogenetic analysis of rDNA sequences only.
Here, we focus on the geographical distribution and pathogenicity of the major nematode species that infect olive trees, along with the symptoms, epidemiology, and management of the diseases they cause. In addition, we address the complex

Table 1. Plant-parasitic nematodes associated with olive trees ${ }^{\mathrm{a}}$

\begin{tabular}{|c|c|c|}
\hline Nematode group and species & $\begin{array}{l}\text { Threshold level } \\
\text { (nematodes } / \mathrm{cm}^{3} \text { soil or } \mathrm{g}^{-1} \text { soil) }\end{array}$ & Country/region \\
\hline \multicolumn{3}{|l|}{ Root-knot nematodes } \\
\hline \multicolumn{3}{|l|}{ Meloidogyne spp. } \\
\hline M. arenaria & - & Spain \\
\hline M. baetica & - & Spain \\
\hline M. hapla & - & Chile, Israel, Portugal \\
\hline M. incognita & - & Argentina, Brazil. Egypt, India, Italy, Jordan, Lebanon, Spain \\
\hline M. javanica & $0.49-0.91$ & $\begin{array}{l}\text { Chile, China, Egypt, Greece, Iran, Italy, Jordan, Libya, } \\
\text { Pakistan, Portugal, Spain, USA }\end{array}$ \\
\hline M. lusitanica & - & Portugal, Spain \\
\hline \multicolumn{3}{|l|}{ Root-lesion nematodes } \\
\hline \multicolumn{3}{|l|}{ Pratylenchoides spp. } \\
\hline P. erzurumensis & - & Turkey \\
\hline P. ritteri & - & Spain, Turkey \\
\hline \multicolumn{3}{|l|}{ Pratylenchus spp. } \\
\hline P. crenatus & - & Italy \\
\hline P. coffeae & - & Australia \\
\hline P. fallax & - & Spain \\
\hline P. mediterraneus & - & Turkey \\
\hline P. neglectus & - & Spain \\
\hline P. penetrans & - & Italy, Spain, Turkey \\
\hline P. thornei & - & Spain \\
\hline P. vulnus & - & Algeria, Italy, Spain, USA \\
\hline P. zeae & - & Turkey \\
\hline Zygotylenchus guevarai & - & Spain, Turkey \\
\hline \multicolumn{3}{|l|}{ Cyst nematodes } \\
\hline Heterodera mediterranea & - & Italy, Spain \\
\hline \multicolumn{3}{|l|}{ Reniform and related nematodes } \\
\hline \multicolumn{3}{|l|}{ Rotylenchulus spp. } \\
\hline R. macrodoratus & - & Greece, Italy \\
\hline R. macrosoma & $0.5-1.0$ & Israel, Spain, Turkey \\
\hline R. reniformis & - & Egypt, Greece \\
\hline Trophotylenchulus saltensis & - & Jordan \\
\hline Tylenchulus semipenetrans & - & Australia, Chile, Greece, Italy, USA \\
\hline \multicolumn{3}{|l|}{ Stunt, awl, and spiral nematodes } \\
\hline \multicolumn{3}{|l|}{ Amplimerlinius spp. } \\
\hline A. amplus & - & Portugal \\
\hline A. dubius & - & Turkey \\
\hline A. macrurus & - & Jordan \\
\hline A. paraglobigerus & - & Spain \\
\hline Aorolaimus perscitus & - & Spain \\
\hline Bitylenchus goffarti & - & Turkey \\
\hline Dolichodorus heterocephalus & - & Italy \\
\hline \multicolumn{3}{|l|}{ Helicotylenchus spp. } \\
\hline H. digonicus & - & Cyprus, Jordan, Spain, Turkey \\
\hline H. dihystera & - & Cyprus, Egypt, Jordan, Spain, Zimbabwe \\
\hline H. erithrinae & - & Italy \\
\hline H. neopaxili & - & Italy \\
\hline H. oleae & - & Italy \\
\hline H. pseudorobustus & - & Greece, Italy, Spain \\
\hline H. tunisiensis & - & Israel, Jordan, Spain, Turkey \\
\hline H. vulgaris & - & Portugal, Spain, Turkey \\
\hline Hoplolaimus aorolaimoides & - & Portugal \\
\hline Hoplolaimus galeatus & - & Turkey \\
\hline Paratrophurus loofi & - & Spain \\
\hline Plesiorotylenchus striaticeps & - & Turkey \\
\hline \multicolumn{3}{|l|}{ Rotylenchus spp. } \\
\hline R. buxophilus & - & Turkey \\
\hline R. cypriensis & - & Turkey \\
\hline R. robustus & - & Portugal \\
\hline Quinisulcius acutus & - & Turkey \\
\hline Scutylenchus lenorus & - & Turkey \\
\hline
\end{tabular}

${ }^{a}$ Data from the following references: $2,11,12,20-22,26,28,36,37,39,42,50,51,59,64,65,70,73,74,79,80,93,95,96$. 
interactions that occur between some nematodes and Verticillium wilt of olive caused by the soilborne fungus Verticillium dahliae Kleb. Finally, we propose effective measures for nematode management in olive nurseries, which are of paramount importance for the production of nematode-free olive planting stock.

\section{Root-Knot Nematodes}

Root-knot nematodes, Meloidogyne spp., are among the most damaging plant pathogens worldwide (40). Meloidogyne species known to damage olive trees are well adapted to temperate and subtropical areas and include Meloidogyne arenaria (Neal, 1889) Chitwood, 1949; Meloidogyne baetica Castillo, Vovlas, Subbotin

Table 1. (continued from previous page)

\begin{tabular}{|c|c|c|}
\hline Nematode group and species & $\begin{array}{c}\text { Threshold level } \\
\text { (nematodes } / \mathrm{cm}^{3} \text { soil or } \mathrm{g}^{-1} \text { soil) }\end{array}$ & Country/region \\
\hline \multicolumn{3}{|l|}{ Tylenchorhynchus spp. } \\
\hline T. aduncus & - & Spain \\
\hline T. claytoni & - & Cyprus, Turkey \\
\hline T. clarus & - & Jordan, Spain \\
\hline T. dubius & - & Greece, Spain \\
\hline T. cylindricus & - & Turkey \\
\hline T. goffarti & - & Jordan \\
\hline T. huesingi & - & Spain \\
\hline T. mamillatus & - & Spain \\
\hline T. penniseti & - & Turkey \\
\hline T. striatus & - & Greece \\
\hline T. tenuis & - & Jordan \\
\hline T. tritici & - & Turkey \\
\hline \multicolumn{3}{|l|}{ Ring, shethoid, and pin nematodes } \\
\hline Criconema princeps & - & Portugal \\
\hline Criconemoides informis & - & Jordan, Spain \\
\hline Gracilacus peratica & - & Italy, Portugal, Spain \\
\hline Gracilacus teres & - & Spain \\
\hline Hemicriconemoides gaddi & - & Turkey \\
\hline Hemicycliophora sturhani & - & Turkey \\
\hline \multicolumn{3}{|l|}{ Mesocriconema spp. } \\
\hline M. curvatum & - & Spain \\
\hline M. olearum & - & Jordan \\
\hline M. onoense & - & Brazil \\
\hline M. siculum & - & Italy \\
\hline M. spaherocephalum & - & Spain \\
\hline M. xenoplax & - & Spain \\
\hline Ogma civellae & - & Zimbabwe \\
\hline Ogma rhombosquamatum & - & Italy, Portugal, Spain \\
\hline \multicolumn{3}{|l|}{ Paratylenchus spp. } \\
\hline$P$. arculatus & - & Spain, Turkey \\
\hline P. baldacii & - & Spain \\
\hline P. microdorus & - & Spain \\
\hline P. nanus & - & Spain \\
\hline P. sheri & - & Spain \\
\hline P. vandenbrandei & - & Italy \\
\hline \multicolumn{3}{|c|}{ Dagger, needle, and stubby-root nematodes } \\
\hline \multicolumn{3}{|c|}{ Xiphinema spp. } \\
\hline$X$. aequит & - & Italy \\
\hline$X$. barense & - & Italy \\
\hline X. californicum & - & USA \\
\hline X. elongatum & - & Egypt \\
\hline$X$. index & - & Greece \\
\hline$X$. ingens & - & Italy, Jordan \\
\hline$X$. italiae & - & Italy \\
\hline X. macroacanthum & - & Italy \\
\hline X. pachtaicum & - & Italy, Jordan, Spain \\
\hline$X$. sahelense & - & Spain \\
\hline X. turcicum & - & Spain \\
\hline X. vuittenezi & - & Spain \\
\hline \multicolumn{3}{|l|}{ Longidorus spp. } \\
\hline L. africanus & - & Egypt \\
\hline L. belloi & - & Portugal \\
\hline L. closelongatus & & Greece \\
\hline L. cretensis & - & Greece \\
\hline L. macrosoma & - & Spain \\
\hline L. siddiqii & - & Jordan \\
\hline L. vinearum & - & Portugal \\
\hline \multicolumn{3}{|l|}{ Paratrichodorus spp. } \\
\hline P. minor & - & Spain \\
\hline P. teres & - & Spain \\
\hline \multicolumn{3}{|l|}{ Trichodorus spp. } \\
\hline T. giennensis & - & Spain \\
\hline T. primitivus & - & Portugal \\
\hline T. taylori & - & Italy \\
\hline
\end{tabular}


\& Troccoli, 2003; Meloidogyne hapla Chitwood, 1949; Meloidogyne incognita (Kofoid \& White, 1919) Chitwood, 1949; M. javanica; and Meloidogyne lusitanica Abrantes \& Santos, 1991 (Table 1, Fig.1). They occur in sporadic distributions in wild olive, olive nurseries, and established orchards, and cause heavy root galling (Fig. 2) and plant growth retardation in pathogenicity tests $(22,45,70,85,86)$. The economic importance of these nematodes in olive cultivation has increased in recent years because most chemical agents for the control of plant-parasitic nematodes have been banned due to environmental and health concerns.

Meloidogyne species are obligate biotrophic pathogens with evolved strategies for infecting thousands of plant species in a similar manner, probably by manipulating fundamental elements of plant cell development (40). Infections by root-knot nematodes induce formation of permanent feeding cells, the giant cells, and stelar destruction in olive roots (Fig. 3). Hyperplasia of the surrounding cells leads to the formation of typical root galls, the primary visible symptom of infection (Figs. 2 and 3). Preferred feeding sites are primary phloem or adjacent undifferentiated parenchyma cells (70). Low to intermediate levels of olive root infections by root-knot nematodes result in moderate root galling in most olive cultivars tested under controlled conditions, as was previously observed in naturally infested rootstocks from olive nurseries in Andalusia, southern Spain $(67,70,85,86)$.

Pathogenicity assays under controlled environmental conditions demonstrated the potential of $M$. arenaria race $2, M$. incognita race 1 , and $M$. javanica to damage olive rootstocks (FS 17, DA 12 I) $(85,86)$ and self-rooted olive cultivars Arbequina and Picual (67). Planting stocks of Picual (one of the olive cultivars most extensively grown in the Mediterranean Basin) infected by Meloidogyne spp. showed a distinct yellowing affecting the uppermost leaves, followed by partial defoliation (Fig. 4). Symptoms were more severe on $M$. arenaria- and $M$. javanica-infected plants than on $M$. incognita-infected plants. Tolerance limits for inoculum (87) of $M$. javanica on cultivars FS 17 and DA 12 I grown under greenhouse conditions were established at 0.49 and 0.61 second-stage juveniles (J2)/g soil, respectively (Fig. 5); and minimum yields near $50 \%$ were estimated for seedling growth $(85,86)$. Studies on the pathogenicity of Meloidogyne spp. to olives suggest that main stem diameter is a highly sensitive parameter for assessing damage caused by $M$. arenaria and $M$. javanica $(67,85)$. A new species, $M$. baetica, was recently described from wild olives in Spain (22). Although the economic importance of this nematode on cultivated olive is still unknown, the histopathological response of Arbequina and Picual olives was similar to that reported for other root-knot species. This may indicate a potential risk for olive growing if this nematode species is widely distributed (22). Long-term experiments under field or microplot conditions are needed to further assess the damaging potential of these nematodes to growth and yield of the most extensively grown olive cultivars.

\section{Root-Lesion Nematodes}

Root-lesion nematodes are obligate migratory endoparasites that damage olive roots by feeding in the cortical parenchyma, causing extensive necrosis of cortical and endodermal cells (20). Infection of olive roots by Pratylenchus spp. causes cortical lesions and reduces root number and size. Both root penetration and migration of the nematode within root tissues are facilitated by a combination of stylet thrusting and enzymatic softening of the host cell walls (104). Although a large number of root-lesion nematode species were found associated with olive in disease surveys (Table 1), artificial inoculations of self-rooted olive plants demonstrated that most of these species do not reproduce on olive (67) and should be considered non-

Table 2. Differential morphological traits among Meloidogyne species infecting olive trees ${ }^{\mathrm{a}}$

\begin{tabular}{|c|c|c|c|c|c|c|}
\hline & M. arenaria & M. baetica & M. hapla & M. incognita & M. javanica & M. lusitanica \\
\hline \multicolumn{7}{|l|}{ Female } \\
\hline Stylet length & $15.5(14.4-15.8)$ & $17.5(17-19)$ & $15(13-17)$ & $14(13-16)$ & $17.0(14.0-18.0)$ & $17(16-19)$ \\
\hline Knobs shape & $\begin{array}{l}\text { Rounded and } \\
\text { backwardly } \\
\text { directed }\end{array}$ & $\begin{array}{l}\text { Ovoid, sloping } \\
\text { backwards }\end{array}$ & $\begin{array}{l}\text { Relatively small, } \\
\text { rounded and set off }\end{array}$ & $\begin{array}{l}\text { Rounded or } \\
\text { drawn out } \\
\text { laterally }\end{array}$ & Rounded & $\begin{array}{l}\text { Ovoid and } \\
\text { backwardly } \\
\text { directed }\end{array}$ \\
\hline $\mathrm{EP} / \mathrm{ST}^{\mathrm{b}}$ ratio & 2.4 & $0.7(0.5-0.8)$ & 3.0 & 1.4 & 2.8 & $2.6(1.6-3.8)$ \\
\hline Perineal pattern & $\begin{array}{l}\text { Round to oval with } \\
\text { dorsal arch low, } \\
\text { striae fairly widely } \\
\text { separated and lateral } \\
\text { field usually marked } \\
\text { by some forked and } \\
\text { broken striae }\end{array}$ & $\begin{array}{l}\text { Distinct inner striae } \\
\text { forming two distinct } \\
\text { longitudinal bands, } \\
\text { extending } \\
\text { throughout the } \\
\text { perineum to just } \\
\text { below the vulva }\end{array}$ & $\begin{array}{l}\text { Rounded with low } \\
\text { dorsal arch, with } \\
\text { punctations in tail } \\
\text { terminus area }\end{array}$ & $\begin{array}{l}\text { Striae closely } \\
\text { spaced, very } \\
\text { wavy to zig- } \\
\text { zag, dorsal arch } \\
\text { high }\end{array}$ & $\begin{array}{l}\text { Striae interrupted } \\
\text { laterally by } \\
\text { conspicuous } \\
\text { double incisures } \\
\text { edging lateral } \\
\text { ridges }\end{array}$ & $\begin{array}{l}\text { Striking, trapezoid } \\
\text { with coarse striae } \\
\text { and medium to } \\
\text { high dorsal arch }\end{array}$ \\
\hline Isozyme $^{c}$ & $\mathrm{~A} 1, \mathrm{~A} 2, \mathrm{~A} 3$ & VS1 & H1 & I1 & $\mathrm{J} 3$ & A1 \\
\hline phenotype & N1 & N1c & H1 & N1 & N1 & P3 \\
\hline \multicolumn{7}{|c|}{ Infective second-stage juvenile $\left(\mathrm{J}_{2}\right)$} \\
\hline \multirow[t]{2}{*}{ Body length } & $(450-490)$ & & & & & \\
\hline & $738(510-1.012)$ & 403 (394 to 422$)$ & $337(360-500)$ & $371(337-403)$ & $417(387-459)$ & $450(390-515)$ \\
\hline Stylet length & $11.6(11.1-12.6)$ & $13.5(13-14)$ & $9.7(7.9-10.9)$ & $10.5(9.6-11.7)$ & $10.4(9.4-11.4)$ & $14.2(13-16)$ \\
\hline Hemizonid position & $\begin{array}{l}\text { Anterior, not } \\
\text { adjacent to EP }\end{array}$ & $\begin{array}{c}\text { 2-3 annuli anterior } \\
\text { to EP }\end{array}$ & $\begin{array}{l}\text { Anterior, not } \\
\text { adjacent to EP }\end{array}$ & $\begin{array}{c}\text { Just anterior to } \\
\text { EP }\end{array}$ & $\begin{array}{l}\text { Immediately } \\
\text { anterior to EP }\end{array}$ & $\begin{array}{l}\text { One or two annuli } \\
\text { anterior to EP }\end{array}$ \\
\hline Tail length & $55.8(52.2-59.9)$ & $50(47-54)$ & $(48-70)$ & $48.7(45-52)$ & $49(36-56)$ & $44(39-50)$ \\
\hline $\begin{array}{l}\text { Tail hyaline portion } \\
\text { Male }\end{array}$ & $14.8(10.8-19.8)$ & $12(10-13)$ & $(12-19)$ & $8.9(6.3-13.5)$ & $13.7(9.8-18.0)$ & $12(10-14)$ \\
\hline Stylet length & $23.5(20.7-25.0)$ & $21.6(20.7-23.4)$ & $20.5(19-22)$ & $24.8(24.3-26.1)$ & $20.3(18.9-23.4)$ & $24.5(21-27)$ \\
\hline Knobs shape & $\begin{array}{c}\text { Ovoid and } \\
\text { backwardly sloping }\end{array}$ & $\begin{array}{l}\text { Smoothly rounded } \\
\text { to stylet }\end{array}$ & $\begin{array}{l}\text { Relatively small, } \\
\text { rounded, set off }\end{array}$ & $\begin{array}{l}\text { Rounded with } \\
\text { flat, concave or } \\
\text { toothed anterior } \\
\text { margins }\end{array}$ & $\begin{array}{l}\text { Low and wide, } \\
\text { often anteriorly } \\
\text { indented, and set } \\
\text { off from the shaft }\end{array}$ & $\begin{array}{l}\text { Elongate, pear } \\
\text { shaped, slightly set } \\
\text { off from shaft }\end{array}$ \\
\hline \multirow{2}{*}{$\begin{array}{l}\text { Spicules } \\
\text { Gubernaculum }\end{array}$} & $36.5(35.4-37.9)$ & $27(24-36)$ & $25.7(21.6-28.1)$ & $35(29-40)$ & $29.5(22.9-35.3)$ & $37.9(32.0-44.5)$ \\
\hline & $9.8(9.5-10.7)$ & $8.2(7.2-9.4)$ & $8.2(7.2-9.4)$ & $11.2(9.4-13.7)$ & $8.0(5.7-10.1)$ & $10.2(8.5-12.0)$ \\
\hline
\end{tabular}

a All measurements are in micrometers unless otherwise stated.

${ }^{b} \mathrm{EP} / \mathrm{ST}=$ excretory pore to female anterior end/female stylet length.

c Isozyme phenotypes used are defined by Esbenshade and Triantaphyllou (32). 
pathogenic to olive. In fact, research in our laboratory showed that the reproduction rates of Pratylenchus fallax Seinhorst, 1968; Pratylenchus thornei Sher \& Allen, 1953; and Zygotylenchus guevarai (Tobar Jiménez, 1963) Braun \& Loof, 1966 on Arbequina and Picual olive were less than 1.0 , suggesting that these cultivars are not suitable hosts for those species. These results agree with field observations, which indicate that these lesion nematodes reproduce predominantly on herbaceous hosts and their presence in fruit tree nurseries (including olive) does not imply a major problem for olive nursery production (67,76). Although Pratylenchus coffeae (Zimmermann, 1898) Filipjev \& Schuurmans-Stekhoven, 1941 has been reported on olive in Australia (51), the damage it might cause to olive growth or yield is still unknown. Consequently, the two major species most frequently diagnosed as damaging to olive worldwide are Pratylenchus penetrans (Cobb, 1917) Filipjev \& Schuurmans-Stekhoven, 1941 and Pratylenchus vulnus Allen \& Jensen, 1951 (Fig. 6), which reduced seedling growth in bioassays $(46,67)$.

$P$. penetrans and $P$. vulnus can be differentiated by phylogenetic analysis of sequences of the D2-D3 expansion regions of 28S rRNA and 18S rRNA (92) as well as several differential morphological traits (20) such as (i) rounded spermatheca, postvulval uterine sac 1 to 1.5 vulval body diameter long, and subcylindrical female tail in $P$. penetrans, compared with (ii) oval spermatheca, postvulval uterine sac 2 vulval body diameter long, and conoid female tail with subacute smooth tip in $P$. vulnus. In spite of the abilities of both $P$. penetrans and $P$. vulnus to infect and reproduce in olive planting stocks, usually they do not induce any macroscopic symptoms on either roots or foliage (67). However, 'Manzanilla' olive planting stocks infected with $P$. vulnus were partially defoliated, and weighed $42 \%$ less than noninfected plants (46). Isolates of $P$. vulnus of different geographical origin and host source may vary in pathogenicity to olive. Pinochet et al. (77) showed that a population from rose plants in northeastern Spain failed to reproduce on Arbequina olive. In contrast, Nico et al. $(67,70)$ found that a population of $P$. vulnus from olive nurseries in Andalusia reproduced well on Arbequina and Picual. Pathogenicity assays under controlled conditions showed that infection by $P$. vulnus and $P$. penetrans significantly reduced the main stem diameter in both cultivars.

Since mixed populations of root-knot and root-lesion nematodes commonly coinfect root systems of olive planting stocks under natural conditions (70), competition between and among nematode species within roots may influence host-parasite interactions. Lamberti et al. (47) reported that the reproduction of $P$. vulnus in 'Leccino' and 'Pendolino' olive plants was significantly reduced by co-infection with M. incognita.

\section{Cyst-Forming Nematodes}

These nematodes are characterized by a cyst stage that allows them to survive in soil for several years in the absence of a host plant. Few cyst nematode species have been reported parasitizing woody plants (8). The cyst-forming nematode, $H$. mediterranea, was found in commercial Manzanilla olive orchards established in sandy soils in southern Spain (21). Artificial inoculations had previously demonstrated the ability of $H$. mediterranea to infect olive plants, thus enlarging the otherwise narrow host range (lentisc, pistachio) known until then (98). Host-parasite studies revealed that sedentary juvenile stages and adult females of $H$. mediterranea have a semi-endoparasitic feeding habit and do not completely penetrate olive roots (Fig. 7) (21). Those studies also showed that the nematode's feeding in olive roots induces syncytia, involving cellular alterations in the cortex, endodermis, pericycle, and vascular parenchyma. For most Heterodera spp., egg hatching as well as orientation toward host tissues is stimulated by host root exudates (8); however, no difference in egg hatching was found between sterile distilled water and dilutions of root exudates from Arbequina and Picual olive planting stocks (Fig. 8) (19). Poor or complete lack of stimulation of egg hatch by root exudates has been suggested as a component of host tolerance to some cyst-forming nematodes (8).

The large populations of $H$. mediterranea found in orchard soils as well as the anatomical alterations in infected olive roots suggest that parasitism by this nematode may contribute to decline of olive seedlings in new plantations or olive nurseries $(19,21)$. Although olive trees infected by $H$. mediterranea do not show any

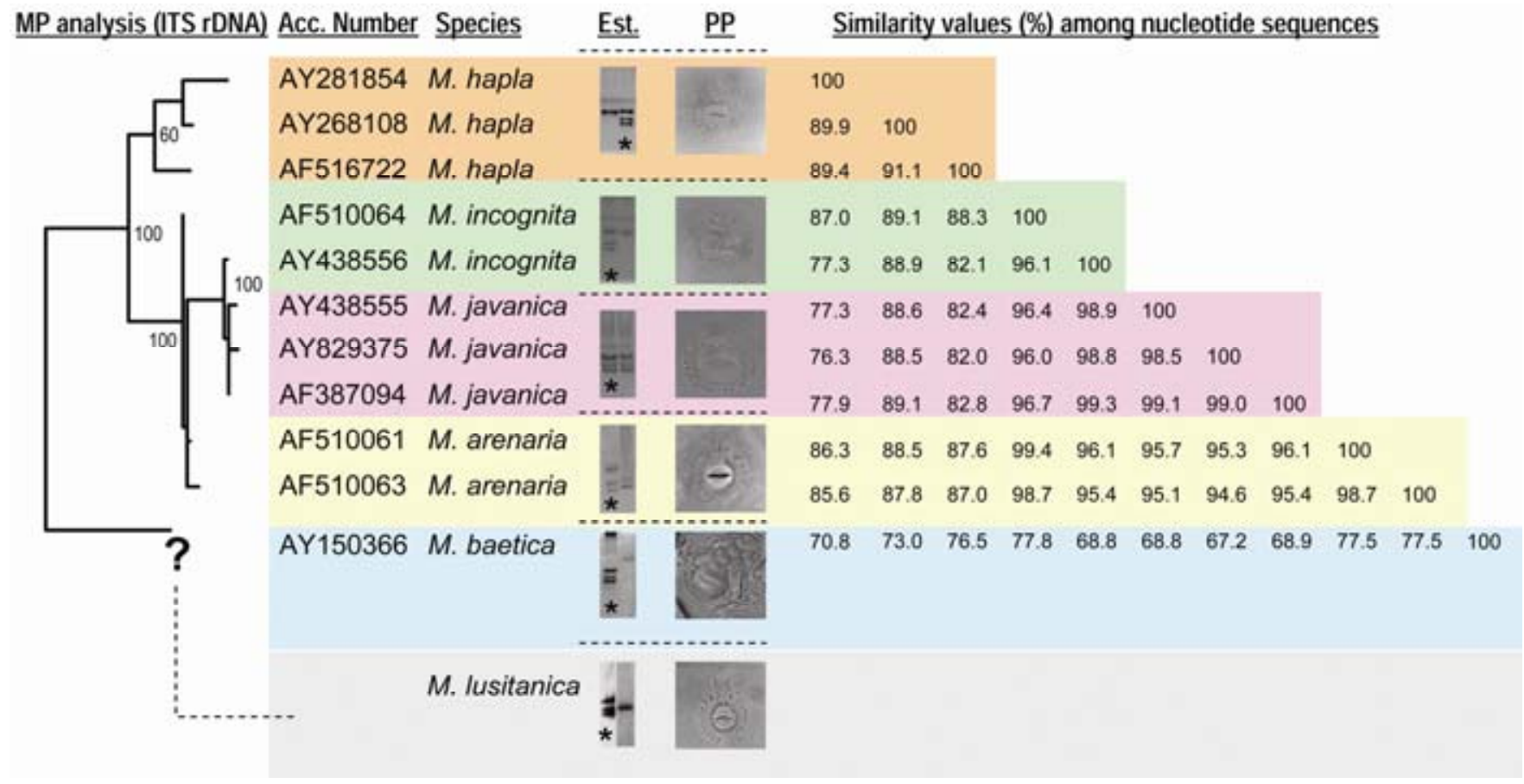

Fig. 1. Polyphasic approach to differentiate the six Meloidogyne species known to infect olive trees. The analysis combines the use of maximum parsimony (MP) analysis of internal transcribed spacer (ITS) regions of ribosomal DNA (rDNA), esterase (Est.) phenotypes compared to that of $M$. javanica, and perineal patterns (PP) (see Table 1 for further details). DNA sequences were not available for M. Iusitanica. 
symptoms on aboveground plant parts, artificial inoculation of self-rooted olive seedlings demonstrated that $H$. mediterranea reproduced on Arbequina (19,21). Pathogenicity assays also showed that plant growth is severely affected by infection with $H$. mediterranea $(10,000$ eggs + second-stage juveniles per plant) with significant reduction of shoot and root dry and fresh weights, as well as shoot height, trunk diameter, and number of nodes in Arbequina but not in Picual (19). The final nematode populations in soil and roots, as well as the reproduction rate and total number of cysts per plant, were significantly higher in Arbequina than in Picual, which confirmed that Arbequina is a better host for $H$. mediterranea.

\section{Reniform and Other Ectoparasitic Nematodes}

Reniform nematodes (Rotylenchulus spp.) are semiendoparasites of roots of herbaceous and woody plants, mainly in tropical and subtropical regions worldwide. Currently, three Rotylenchulus species ( $R$. macrodoratus Dasgupta, Raski \& Sher, 1968; R. macrosoma Dasgupta, Raski \& Sher, 1968; and $R$. reniformis Linford \& Oliveira, 1940) are reported as parasites of olive $(23,96)$. Artificial inoculation of both wild olives and olive cultivars Arbequina and Picual with $R$. macrosoma revealed reproduction factors of 2.5 , 2.2, and 1.9 times the initial population density $\left(\mathrm{P}_{\mathrm{i}}\right)$, respectively (23). The number of free-living stages of the nematode (juveniles, males, and immature females) and sedentary mature females in soil and roots, as well as the final population density and reproduction rate, did not differ significantly between wild and cultivated olives; however, there was no clear evidence of actual growth impairment in infected plants.

$R$. macrosoma survives in soil in the juvenile and adult male stages. Immature females penetrate the root and become established in the endodermis (23). The feeding site induced by $R$. macrosoma in olive roots consists of a stelar syncytium, which originates from an endodermal cell enlarging near a curved sheet of pericycle cells formed by hypertrophy of pericycle cells (Fig. 9). Clear anatomical differences in the feeding site distinguish infection by $R$. macrodoratus from that by $R$. macrosoma. $R$. macrodoratus causes the formation of an enlarged uninucleate stelar or cortical "nurse cell" with dense cytoplasm and hypertrophic nucleolus (uninucleate giant cell) (96), whereas $R$. macrosoma forms a syncytium (Fig. 9). For both species, the kidney-shaped females produce a gelatinous matrix that covers the female body in which about 50 eggs are laid. Usually, soil adhering to this matrix blocks detection of the female on the root surface.

In addition to Rotylenchulus spp., a number of rather specialized sedentary ectoparasitic nematodes attack olive: the citrus biotype of the citrus nematode $T y$ lenchulus semipenetrans infects olive trees in California, Chile, and Italy (52,59);
Gracilacus peratica (Fig. 10) and Ogma rhombosquamatum (Mehta \& Raski, 1971) Andrássy, 1979 were observed feeding on olive roots (280 to 360 nematodes/g fresh
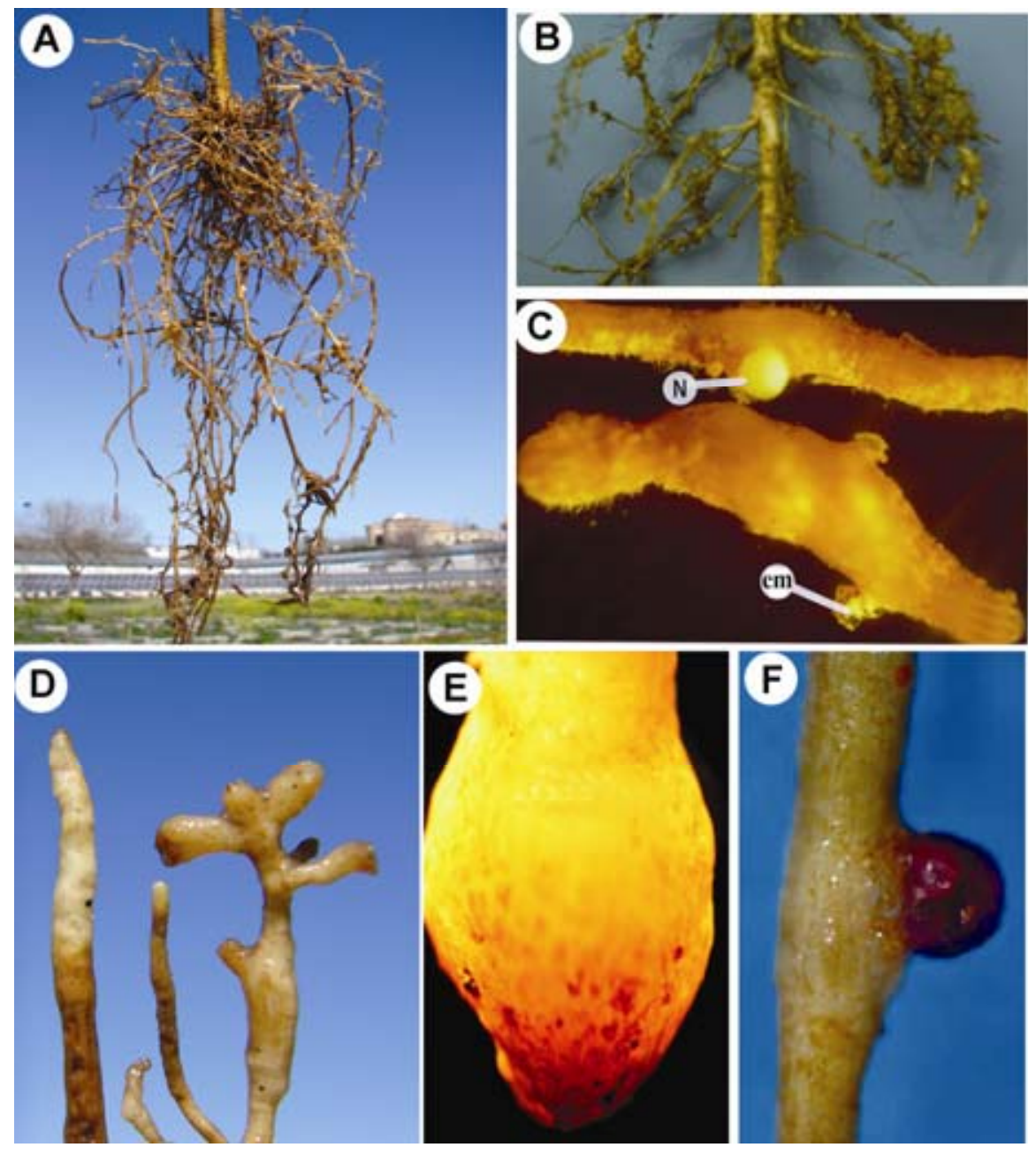

Fig. 2. A, Olive root system severely infected with root-knot nematodes; note small galls. B, Root galls caused by Meloidogyne javanica. C, Details of adult Meloidogyne incognita female (N) and egg mass (em). D and E, Details of typical galled olive root tip due to infection by Meloidogyne spp. F, Detail of Meloidogyne spp. egg mass stained with phloxine $B$.
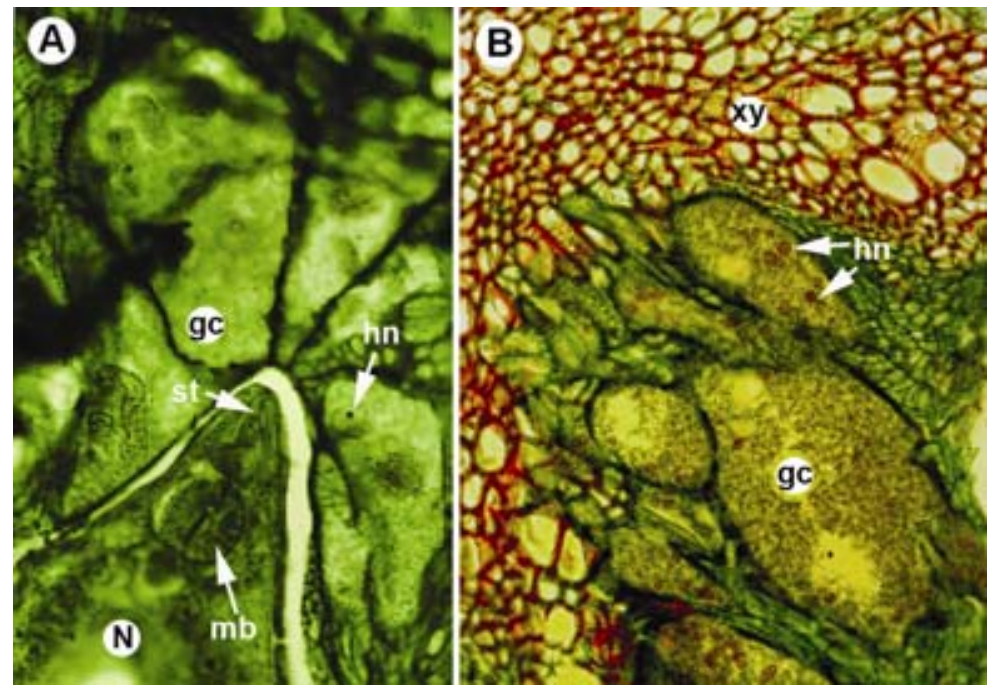

Fig. 3. Cross section of a young olive root (cv. Arbequina) infected by Meloidogyne arenaria. A, Detail of the lip region of an adult female $(\mathrm{N})$ showing the stylet (st), median bulb (mb), and induced giant cells (gc) with hypertrophied nuclei (hn). B, Detail of a feeding site showing xylem (xy) and giant cells with hypertrophied nuclei. 
root) in Italy and Spain $(36,70,97)$; and Trophotylenchulus saltensis Hashim, 1984 was found parasitizing olives in Jordan, but damage to the plant was not studied (51). The cortical root cells on which Gracilacus peratica Raski, 1962 fed showed thickened and lignified walls near the site of stylet penetration as well as a feeding tube associated with nematode salivation (Fig. 10) (36). Females of $O$. rhombosquamatum remained attached to the olive root by the stylet, which penetrated the epidermis and two to three layers of cortical cells. Nematode feeding activity induced thickening of cortical cell walls and hypertrophy of the nucleus and nucleolus, which appeared 4 to 5 times larger than those of normal cortical cells (97). However, convincing evidence of pathogenicity by the above nematodes to olive has only been demonstrated for high infection levels of $T$. semipenetrans $(52,59)$.

Other plant-parasitic nematodes associated with olive comprise a long list of migratory ectoparasites, including spiral, dagger, needle, stunt, and stubby-root nematode species (Table 1). Several species of ectoparasitic spiral nematodes of the genus Helicotylenchus have been associated with olive roots (Table 1), some of which were associated with necrosis in olive roots and were considered capable of affecting olive tree growth under particular growing conditions (37), including $H$. digonicus Perry, in Perry, Darling \& Thorne, 1959; H. dihystera (Cobb, 1893) Sher, 1961; H. erythrinae (Zimmermann, 1904) Golden, 1956; H. pseudorobustus (Steiner, 1914) Golden, 1956; and H. oleae Inserra, Vovlas \& Golden, 1979. In general, Helicotylenchus spp. can adopt semiendoparasitic feeding positions on olive feeder roots (Fig. 11).

Xiphinema and Longidorus nematodes cause damage to olive by feeding on unmodified plant root cells. However, some species are also capable of transmitting viruses, leading to diseases in a wide range of fruit and vegetable crops (58). Olive is reported as a natural host of nepoviruses

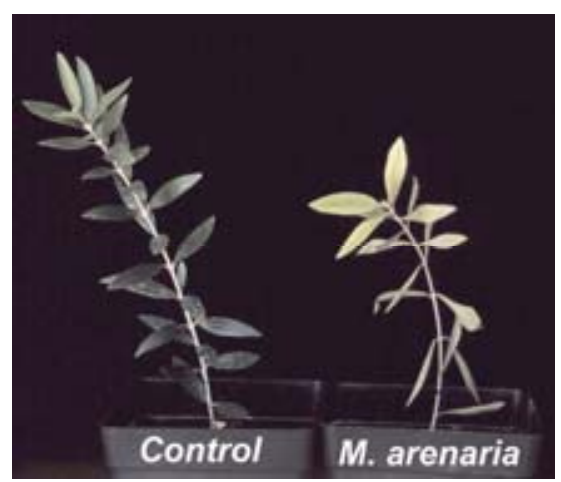

Fig. 4. Aboveground symptoms of olive plant cv. Arbequina infected by Meloidogyne arenaria (right) showing a distinct yellowing in uppermost leaves. Uninoculated control to the left. transmitted by Xiphinema diversicaudatum (Micoletzky, 1927) Thorne, 1939 and Xiphinema vuittenezi Luc, Lima, Weischer \& Flegg, 1964 (58) viz., Arabis mosaic virus (ArMV), Strawberry latent ringspot virus (SLRV), and Cherry leaf roll virus (CLRV). However, none of these viruses cause a specific syndrome in olive except for SLRV, which has been found associated with striking malformations of leaves and fruits of cv. Ascolana tenera (57). Xiphinema elongatum Schuurmans Stekhoven \& Teunissen, 1938 has been shown to reduce top weight of olive plantlets by $65 \%$ in Egypt (51). Xiphinema index Thorne \& Allen, 1950, which often occurs in the rhizosphere of grapevine plants and fig trees, has also been found in olive nurseries and olive orchards in Italy (83). Several olive cultivars were demonstrated to be suitable hosts for $X$. index, but olive cv. FS 17 and rootstock DA 12 I were found to be resistant to the nematode (83). Resistance of olive to $X$. index was correlated with phenol content and peroxidase activity in leaves and roots (78).

\section{Interactions Between Nematodes and Fungi in Olive}

Nematode damage to olive roots may also predispose olive trees to other pathogens. The best-known interaction between plant-parasitic nematodes and other olive pathogens is that of root-knot nematodes and Verticillium dahliae, the causal agent of Verticillium wilt. M. javanica and $V$. dahliae caused considerable damage to olive orchards in the northern part of Iran, and the growth of olive cv. Zard seedlings inoculated with these two pathogens was significantly reduced compared with that of seedlings inoculated with each pathogen alone (82). Similarly, the proportion of chlorotic, wilted, and necrotic leaves of seedlings was highest in plants simultaneously inoculated with both pathogens. In contrast, studies by Lamberti et al. (49) of olive cultivars Leccino and Pendolino failed to show any significant interaction between infections by $V$. dahliae and $M$. incognita and between $V$. dahliae and $P$. vulnus, but the authors suggested that a longer duration of the experiments might be needed to demonstrate interactions between the pathogens. The mechanism of interaction and the precise role of each component in a disease complex have to be further investigated. These results suggest that interactions between plant-parasitic nematodes and fungi can vary considerably over plant genotypes, cultivars, or lines. In Argentina, the etiology of a generalized olive drying syndrome (designated "seca") was attributed to a disease complex involving $M$. javanica and several species of the soilborne fungus Fusarium, although a causal relationship has not been established $(15,75)$.

\section{Control of Nematode Diseases on Olive}

Exclusion. Exclusion is the first control strategy to be considered for management of plant-parasitic nematodes on olive. Heavy infestations of plant pathogens in agroecosystems can often be traced back to accidental introductions at the initial stages of crop development (91). Preventing the

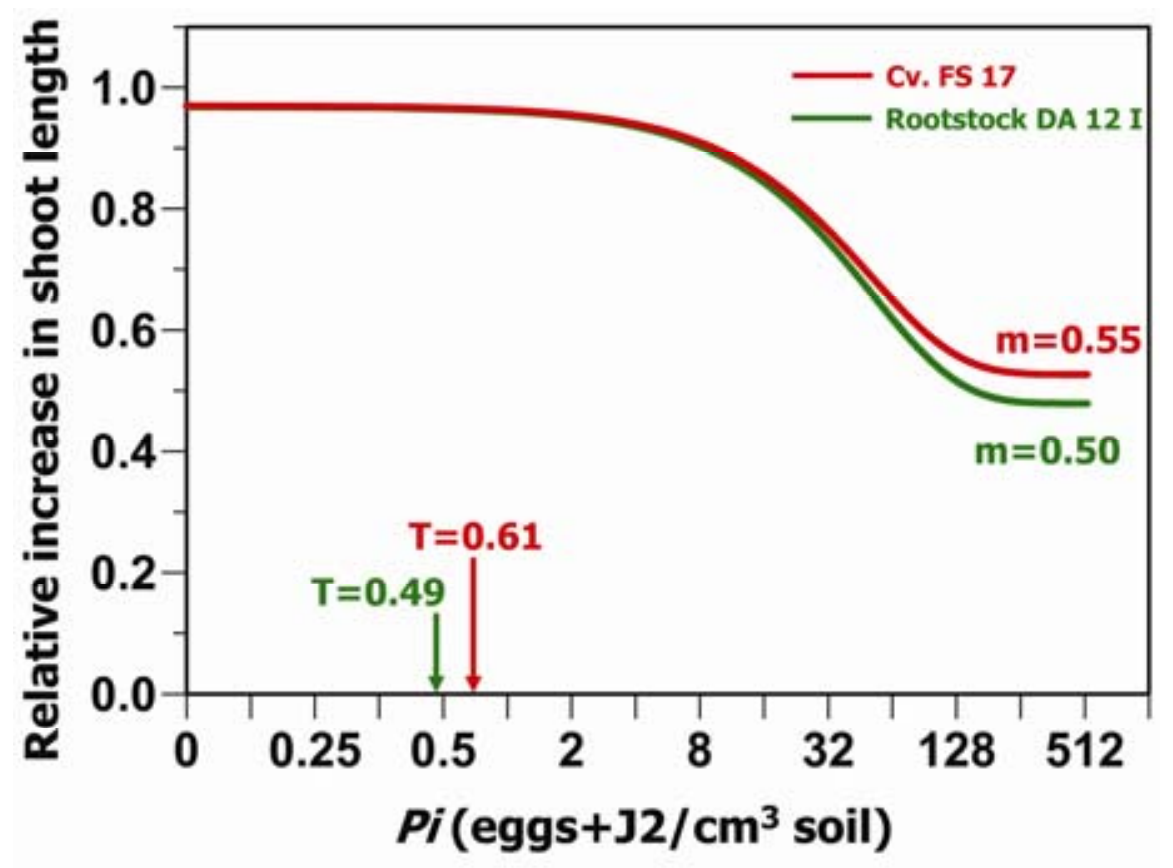

Fig. 5. Relationships between relative shoot length olive cv. FS 17 and rootstock DA 12 I and initial population density $(\mathrm{Pi})$ of Meloidogyne javanica. Abbreviations: $\mathrm{m}=$ minimum value of relative shoot length (relative length at very large $P i$ values; $T=$ tolerance limit. 
entry of plant-parasitic nematodes into the agroecosystem must be implemented first by nursery managers. Modern propagation procedures in olive nurseries include an initial stage in which soft-wood cuttings are rooted in standard growing media such as peat or perlite, followed by a second phase in which rooted cuttings are transplanted to soil-filled containers. Nematode infection is unlikely to occur in the first stage, since growing media are reasonably free from pathogens, and aboveground olive plant parts, such as cuttings, do not contain parasitic nematodes. Consequently, later propagation stages require the use of uninfested soil as an essential measure of nematode exclusion. In fact, control measures for plant-parasitic nematodes attacking olive have been addressed mainly to nurseries. Planting stocks, especially those containerized such as olive, may act as effective "Trojan horses" that deliver previously absent plant pathogens to the planting site. The potential for future damage to olive production has been taken into account by legislation in Spain $(9,10)$ and the European Union (EU) (30) through mandates for pathogen-free certification programs for olive planting stocks and rootstocks (30). Unfortunately, adoption of certification programs by nurseries is not compulsory in Spain, and therefore its practice is very limited. Under these circumstances, selecting a well-reputed nursery as supplier of planting material may serve as a rational exclusion practice (5). Growers should also choose new plantation sites free of plant-parasitic nematodes in which to establish planting material (56).

The appropriate application of exclusion principles should lead to nematode-free nursery stock. Although this is theoretically possible with the use of nematodefree potting mixtures, many times nursery managers must resort to nematode-infested soil for economic reasons. Disinfestation of soil by any means cannot achieve total nematode control. The use of potting mixtures that are not fully disinfested reduces nematological risk, but could mask the presence of pathogen nematodes in seemingly healthy stock. The need for a tradeoff suggests the need for tolerance thresholds. No such thresholds are standardized for olive, but we suggest adopting the criteria presented by Whitehead (101), who recommended control of at least $95 \%$ of root lesion nematodes and $99.9 \%$ of root-knot nematodes. Although these standards were proposed for annual crops and may therefore be considered unsuitable for longlived perennials like olive, nematode reproduction rates are much lower in woodyperennial than in annual-herbaceous hosts.

Exclusion of olive-parasitic nematodes on a regional basis includes surveillance measures. Three species of fruit crop-infecting nematodes potentially damaging to olive are absent in Europe: Longidorus diadecturus Eveleigh \& Allen, 1982; Xiphinema americanum Cobb, 1913; and $X$. californicum Lamberti \& Bleve-Zacheo, 1979. Consequently, these species have been declared quarantine pests in the EU (31). Other olive-growing countries that have imposed quarantine measures against plant-parasitic nematodes potentially pathogenic to olives include Chile, where $H$. mediterranea and Xiphinema italiae Meyl, 1953 are considered quarantine pests (60).

Chemical control. Chemical measures aim to control nematodes present in the rhizosphere soil or in infected plant tissues, or both. Chemical control may be hampered by uncertain efficacy, environmental hazards, and/or deleterious impact on plants. Available nematicides are classified as fumigants (i.e., gaseous or highly volatile nonspecific biocides) and nonfumigant nematicides (NFNs).

Soil disinfestation with fumigants prior to planting is a nematode control strategy broadly used in some fruit crops. For particular crops, soil disinfestation may even be publicly subsidized, as is the case of grapevine in some Spanish production areas (27). Nevertheless, fumigation is unusual in olive production. A lack of awareness of the damage potential of nematodes probably underlies this fact. Chemical disinfestation of nursery substrates is a suitable approach for production of nematode-free nursery stock. A large number of fumigants or fumigantlike products are available, in spite of an increasing number of failures in re-registration. In Spain, the list currently includes dazomet, metham sodium, metham potassium, and sodium tetrathiocarbonate (61).

The list of NFNs includes a series of organophosphate and carbamate products that display a certain degree of insecticidal and acaricidal effects as well. In Spain, the official list of authorized NFNs pesticides includes ethoprophos, fosthiazate, fenamiphos, and oxamyl, but none are registered for use in olive (61). A similar situation, in which a certain number of specific nematicides are registered but none of them for

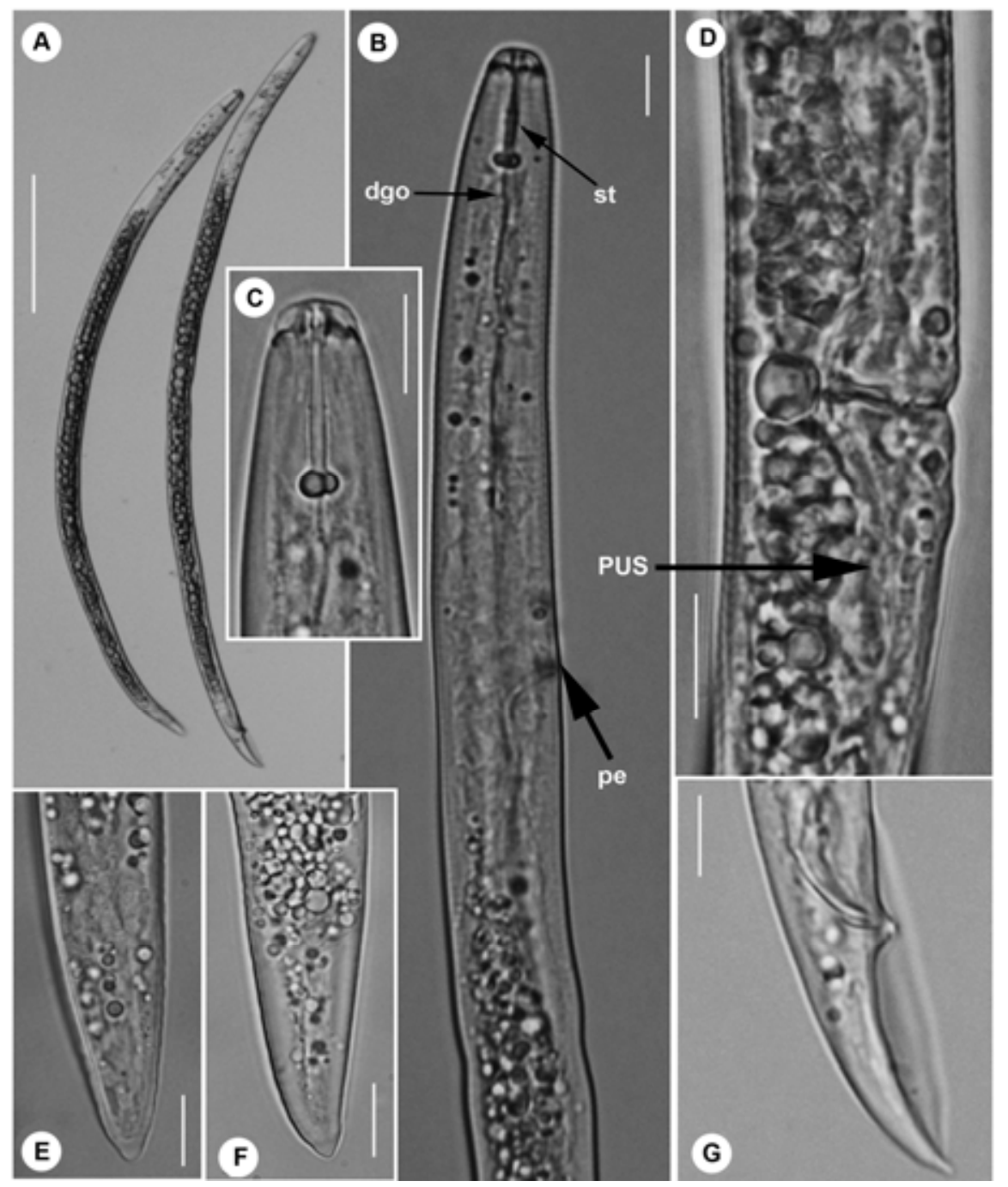

Fig. 6. Micrographs of the root-lesion nematode Pratylenchus vulnus. A, Whole body of female and male. B, Female anterior region showing stylet (st), dorsal pharyngeal gland outlet (dgo), and excretory pore (pe). C, Detail of lip region. D, Female vulval region showing postvulval uterine sac (PUS). E and F, Female tails. G, Male tail. (Scale bars: $A=100 \mu \mathrm{m}$; $B$ to $G=10$ to $\mu \mathrm{m}$ ) 

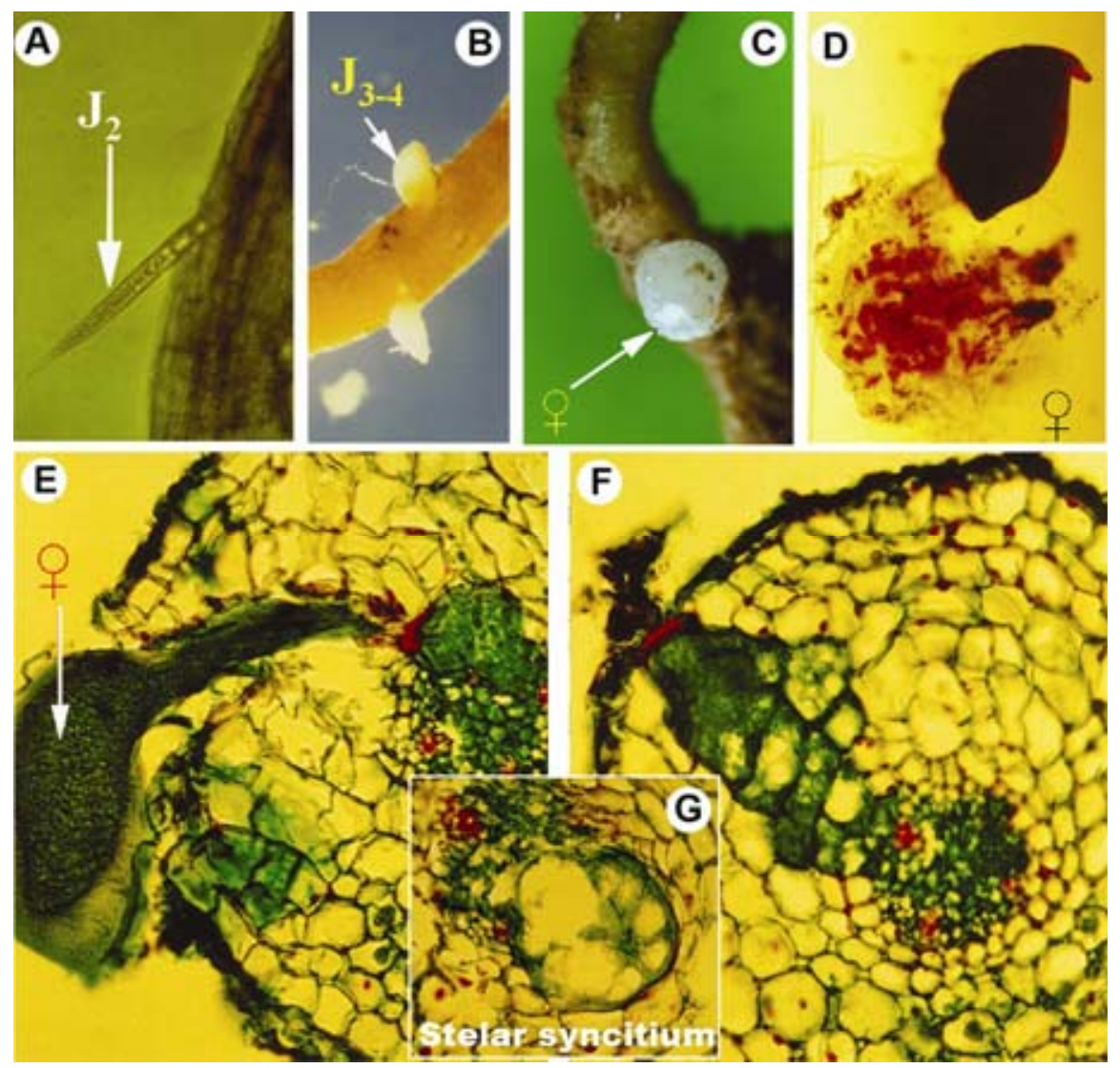

Fig. 7. Natural infections of olive trees cv. Manzanilla by Heterodera mediterranea. A to C, Partially embedded second- $\left(J_{2}\right)$ and third/fourth- $\left(J_{3-4}\right)$ stage juveniles and young cyst (arrow) in young olive roots. D, A mature female showing large gelatinous matrix with eggs. $E$ and $F$, Cross sections of olive roots infected by $H$. mediterranea, showing a syncytium involving endodermal and pericycle cells (deeper stain). G, Magnification of a stelar syncytium showing fused syncytial cells and stelar distortion due to their expansion.

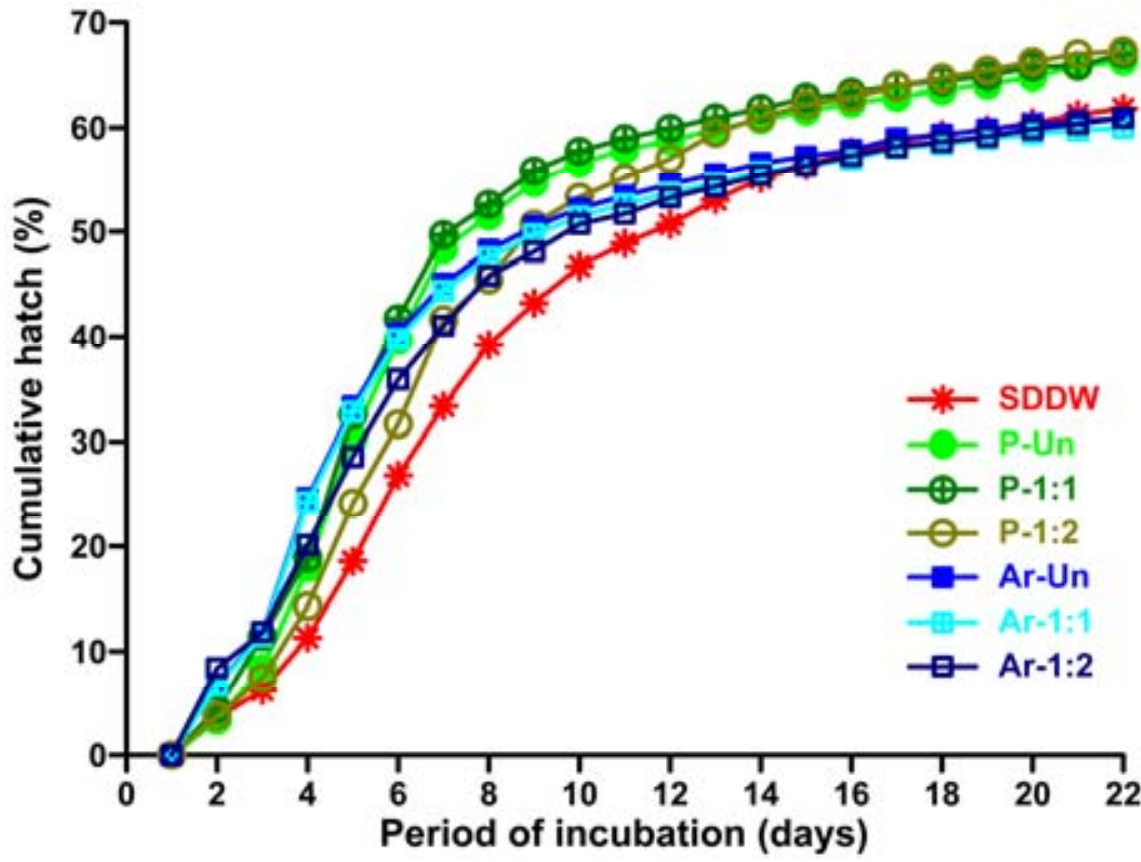

Fig. 8. Cumulative egg hatch of Heterodera mediterranea incubated at $20^{\circ} \mathrm{C}$ in olive root exudates for 22 days. Abbreviations: SDDW = sterile deionized distilled water; PUn = undiluted root exudates from olive planting stock cv. Picual; P-1:1, P-1:2 = root exudates from olive planting stock cv. Picual diluted, respectively, 1:1 or 1:2 with SDDW; Ar-Un = undiluted root exudates from olive planting stock cv. Arbequina; Ar-1:1, Ar-1:2 = root exudates from olive planting stock cv. Arbequina diluted, respectively, 1:1 or 1:2 with SDDW. use in olive, occurs in other olive growing countries such as Australia (6), Argentina (14), Italy (62), and Portugal (89). A misperception of nematological risk discourages pesticide companies from facing registration expenses for new nematicides. If allowed by regulation, NFNs can be used in a wide variety of situations. Experience in other fruit crops supports their application either at pre- or postplanting. In the nursery, NFNs can be applied as dips of bare-root stocks, additions to substrates, or foliar sprays. Dipping was successfully used in Citrus spp. for control of $T$. semipenetrans and Radopholus similis $(71,72)$. Addition of phenamiphos to substrate reduced root-knot nematode infections in olive (48). Because of their systemic nature, spraying of some NFNs onto foliage may also protect roots from infections by soilborne nematodes (1). Vovlas et al. (99) compared the three strategies of application in fruit crops and found that efficacy of NFNs depends mainly on the crop and the nematode target species rather than the application method.

NFNs can be applied postplanting either by chemigation with emulsifiable concentrates, or by mixing granular formulations into the soil. The opportunity for using the latter mode must be checked in each particular country, because the use of granular pesticides is being progressively prohibited by many regulatory agencies due to avian risk (90). There is a scarcity of data concerning postplanting treatment with NFNs in olive orchards. A field trial in Chile (38) compared the effects of fenamiphos chemigation on root growth and development of olive trees naturally infected by $T$. semipenetrans, compared with treatments with a biocontrol formulation and an amendment with organic manure. No significant differences in effects on root mass were found, suggesting that the biocontrol and amendment treatments were as efficient as a chemigation with fenamiphos. In Egypt, Shawky et al. (88) compared the efficacy of recommended rates of five NFNs (fenamiphos, ethoprophos, carbofuran, oxamyl, and aldicarb) for the control of $M$. incognita on olive trees. All nematicides were effective in reducing the number of nematodes in both soil and roots, but fenamiphos gave the greatest reduction in nematodes in soil and the number of galls, females, and egg masses, whereas carbofuran gave the least reduction.

Nonchemical control. Concerns about the eventual environmental impact of the use of pesticides have promoted the development of a number of nonchemical strategies for disinfesting agricultural substrates. One of the most successful is soil solarization, a hydrothermal process whereby moist soil is heated under transparent plastic tarps to temperatures detrimental to soilborne pathogens (41). Olive production takes place at medium-latitude areas of 


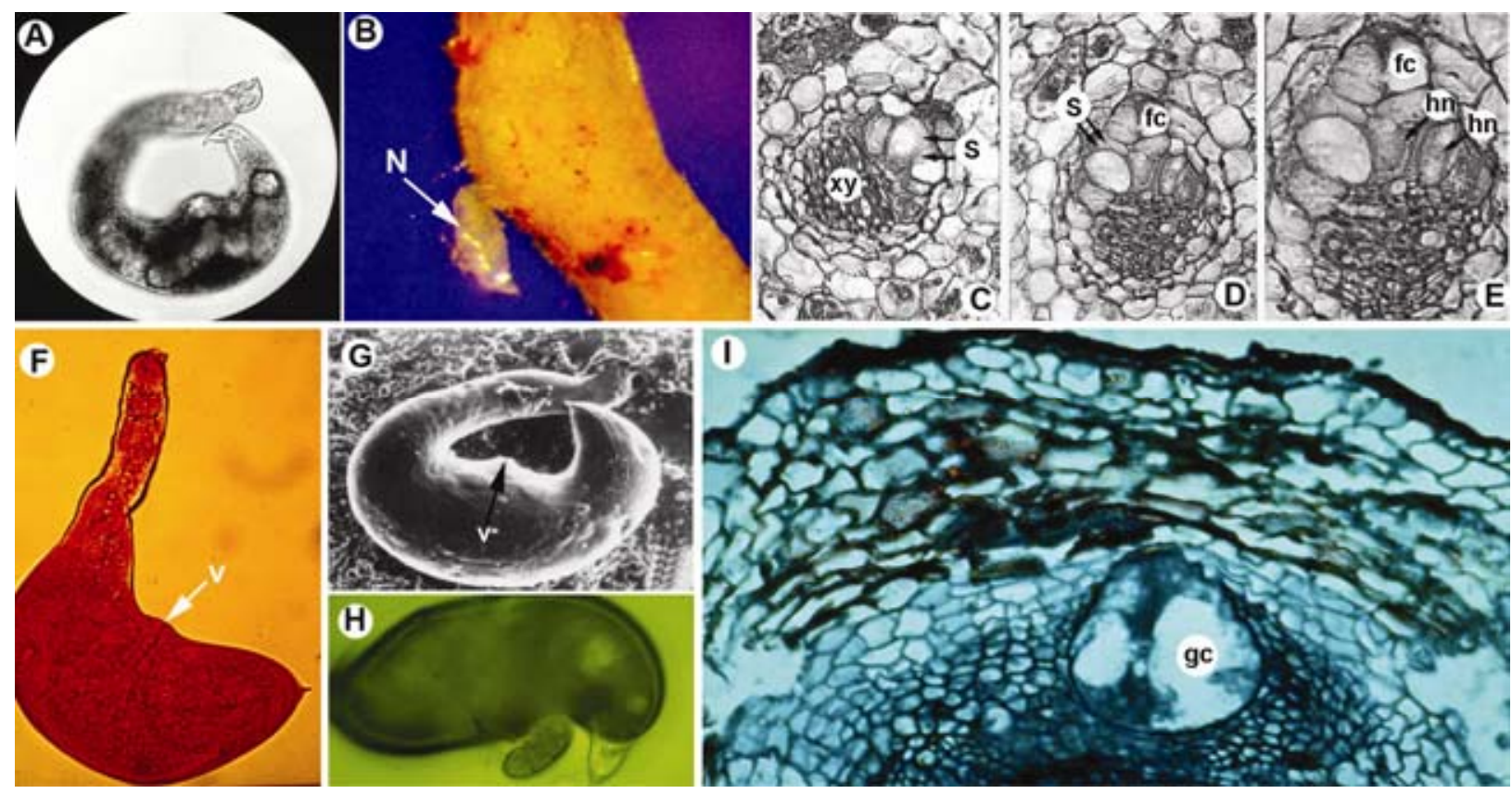

Fig. 9. Reniform nematodes infecting olive trees. A to E, Rotylenchulus macrosoma. A, Micrograph of whole body of female. B, Nematode female attached to a root of wild olive. C to E, Cross sections of olive roots infected by $R$. macrosoma showing feeding cells (fc) and the stelar syncytium (S) with hypertrophied nuclei (hn), stelar distortion and compressed xylem elements (xy). $F$ to I, Rotylenchulus macrodoratus. F, Micrograph of whole body of female. G, Scanning electron micrograph of a nematode female parasitizing an olive root $(\mathrm{v}=$ vulva). $\mathrm{H}$, Detail of vulval region showing an egg outside. I, Cross section of an olive root showing enlarged uninucleate stelar or cortical "nurse cell” (gc).

Mediterranean climate where summer weather offers optimal conditions for soil solarization. Solarization of small piles of nursery substrates used as potting mixtures for glasshouse-grown plants is a novel approach for the management of soilborne plant pathogens (68). Solarization of piled soil (Fig. 12) provided a significant reduction of $M$. incognita eggs and egg masses in soil at a maximum depth of $40 \mathrm{~cm}$ after 10 days of treatment (68). Furthermore, the thermal threshold reached by solarization for inactivating free eggs and egg masses of $M$. incognita may also control other plant-parasitic nematodes potentially hazardous to olive plants, e.g., $P$. vulnus and $P$. penetrans (67).

Solarization might also be used in established orchards to control nematode infestations as it has been done to control other olive soilborne plant pathogens. Tjamos (94) and López-Escudero and BlancoLópez (55) attained a significant reduction in Verticillium wilt incidence when solarization was applied to individual $V$. dahliae-infected olive trees of different ages.

Another environmentally friendly approach for substrate disinfestation is the use of organic amendments (3). Many different agricultural and industrial byproducts have been assayed for this purpose (25). Composts, extensively recommended as potential suppressors of soilborne fungi, have not been adequate for nematode control. Nico et al. (69) tested amendment of olive potting substrate with dry cork compost at different rates for control of $M$. incognita. Nematode numbers in the amended substrate decreased
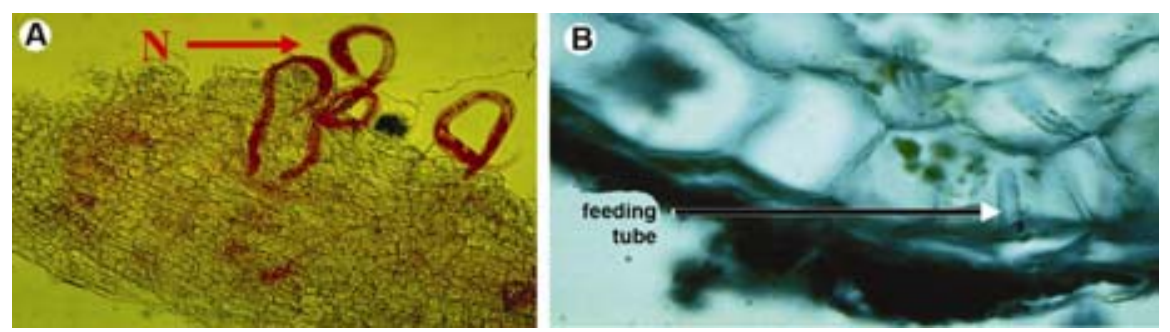

Fig. 10. A, Colonies of mature females (N) of Gracilacus peratica (red-stained with acid fuchsin) infecting olive (cv. Coratina) feeder roots. B, Cross section of an olive feeder root showing the feeding tube in a nematode-infected cortical cell (arrow).

exponentially as the rate of compost increased; whereas the lowest rate of amendment provided a sufficient level of control, the highest suppression occurred using pure compost as substrate (Fig. 13).

Suppression of plant pathogens in soil can be also achieved using special amendments in a process known as biofumigation (43), which is based on the release of biocidal volatiles during breakdown of tissues of some plants, mainly of Brassica and Sorghum species. Biofumigation is often practiced with plastic tarping, in order to confine the volatile compounds produced and enhance their biological effect. The effect of biofumigation with leaf tissues of Sorghum sudanense (Piper) Stapf. on suppression of $M$. incognita was tested in a laboratory with different rates of artificially infested potting mixture as well as times of exposure and use of tarp (A. Nico, R. M. Jiménez-Díaz, and P. Castillo, unpublished). The final nematode population was significantly reduced by treatment in all cases, but the degree of suppression was adequate only when biofumigation lasted for 30 to 60 days. Therefore, biofumigation does not appear to be as efficient as soil solarization as a single control measure for disinfesting soil of plant-parasitic nematodes.

Protection of olive planting with mycorrhizae. Establishment of arbuscular mycorrhizal fungi (AMF) in plant root systems can protect plants against soilborne diseases through improvement of $\mathrm{P}$ absorption, direct competition with pathogens for infection sites and nutrients, and other mechanisms (7). The effectiveness of $\mathrm{AMF}$ in conferring protection against plant-parasitic nematodes was documented in several pathosystems, including Meloidogyne spp. and olive (17). Early inoculation of planting stocks of olive cultivars Arbequina and Picual with Glomus intraradices Schenck \& Smith, G. mosseae (Thaxter) Gerd. \& Trappe, or G. viscosum Nicolson favored plant growth and conferred protection against $M$. incognita race 1 and $M$. javanica by inhibiting nematode 

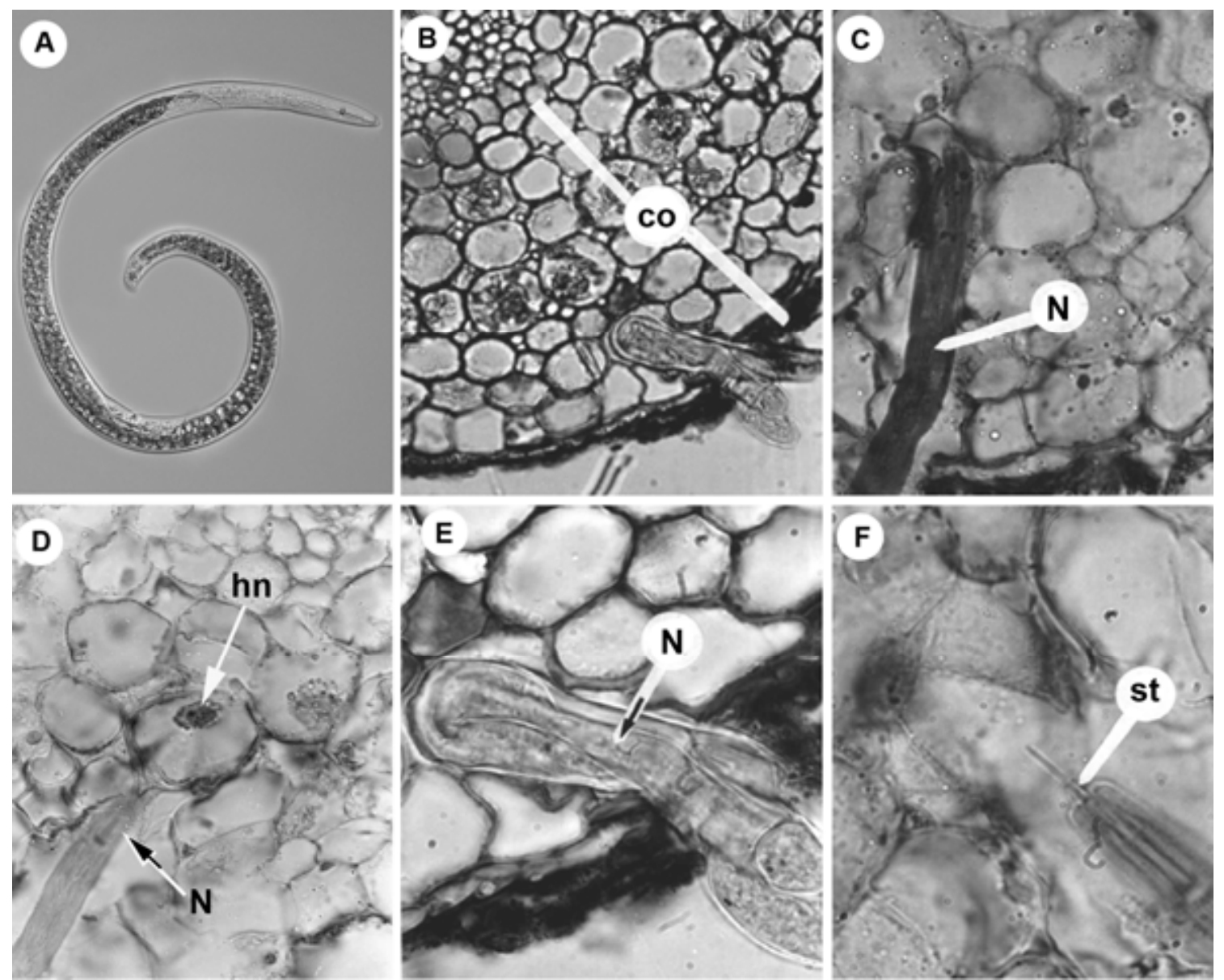

Fig. 11. A, Micrograph of female whole body of Helicotylenchus oleae. B to F, Cross sections of olive roots infected by $H$. oleae. B and E, Details of a coiled nematode specimen $(\mathrm{N})$ in the root cortex (CO). C, D, and F, Details of the lip regions of $H$. oleae (N) penetrating cell walls in the cortex of olive feeder roots (st = stylet; $h n=$ hypertrophic cell nucleus).

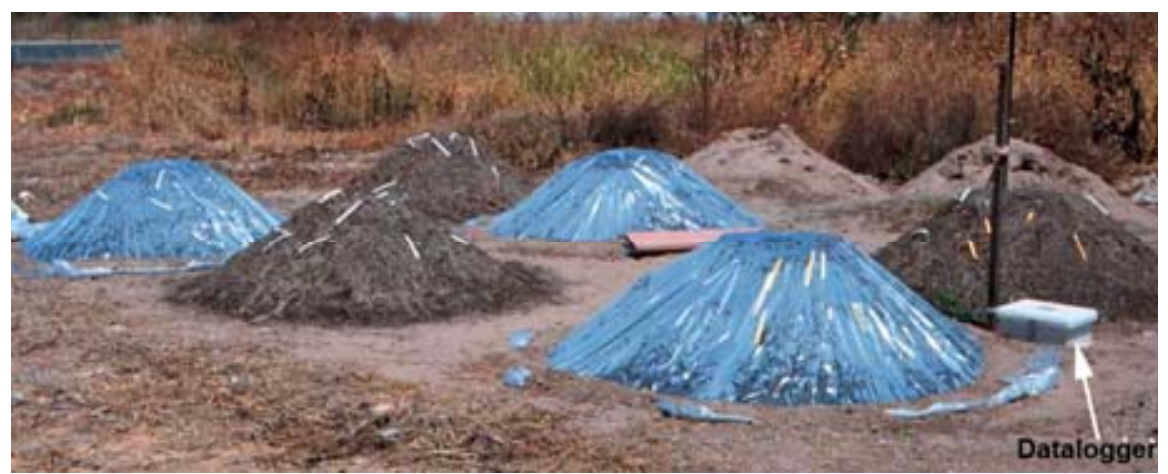

Fig. 12. Conical piles of soil $80 \mathrm{~cm}$ high and with a base diameter of $1 \mathrm{~m}$ solarized for 3 weeks in July at Córdoba, southern Spain, for disinfestation from Meloidogyne incognita eggs and $J_{2}$ placed in nylon bags at a depth of 20 and $40 \mathrm{~cm}$ inside a pile.

reproduction, reducing the severity of root galling, and probably, enhancing olive plant nutrition (17). Consequently, the use of AMF-infected planting material during olive plant propagation in nurseries may be a useful practice for minimizing the effects of root-knot nematodes, as well as for protecting these plants against future nematode infections in commercial olive orchards.

Resistance. Host plant resistance probably offers the easiest, safest, and cheapest long-term approach to minimize damage

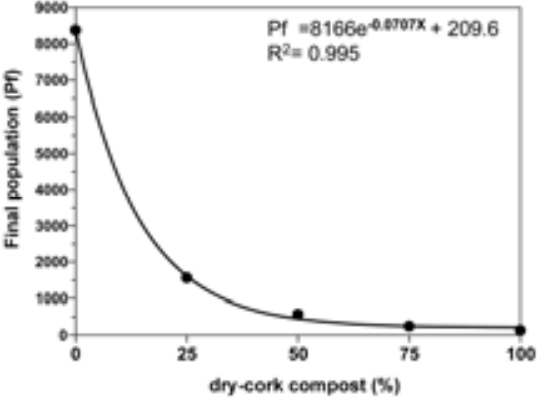

Fig. 13. Relationship between final nematode population of Meloidogyne incognita race 1 on olive planting stocks cv. Picual and the rate of dry cork compost amending a potting mixture $(0$, $25,50,75$, and $100 \%$ ). Each point represents the average of two trials. Lines represent the predicted function calculated by fitting the expanded negative exponential model to data.

resistant rootstocks constitutes a fundamental pillar for root-knot nematode management in some fruit crops, such as Prunus spp. (76). In olive, however, less effort has been dedicated to identifying and using host plant resistance against plant-parasitic nematodes. In part, this may be due to the fact that olive, unlike most fruit crops, is rarely propagated by grafting. Nevertheless, development of resistant rootstocks may be a valuable tool for nematode management in olive, as sug- gested by the successful results obtained with the clonal rootstock 'Allegra' in California (59).

Host resistance to nematodes may vary to a great extent depending on olive cultivar, usually propagated by self-rooting, and nematode species. In Egypt, six olive cultivars were tested for their reaction to 
$M$. incognita and $R$. reniformis (4). Cultivars Meashon and Tofany were found to be resistant to $M$. incognita but moderately susceptible to $R$. reniformis; while cultivars Manzanillo and Egazi were moderately susceptible to $M$. incognita but tolerant of $R$. reniformis, and cultivars Hamed and Bekwal were susceptible to both nematode species (4). Similarly, screening of olive cultivars most commonly used in Italy for resistance against root-knot nematodes showed that cultivar Coratina is resistant to $M$. incognita and $M$. javanica, whereas cultivars Leccino and Yusti are resistant to $M$. javanica and moderately susceptible to $M$. incognita (86). Other cultivars (Cima di Bitonto, Cellina di Nardo, Frantoio, and FS 17) were shown to be moderately susceptible to $M$. incognita (86), whereas the rootstock DA 121 was highly susceptible to $M$. javanica $(85,86)$. The use of in vitro olive explants has proven to be useful in reducing the duration of resistance screening assays of olive germplasm against root-knot nematodes (84).

Miscellaneous. Covering orchard soil with permanent vegetation is becoming one of the most commonly used orchard management systems for preventing soil erosion, improving soil structure and fertility, increasing water infiltration, and reducing surface runoff $(16,35)$. Plant covers are usually natural flora, and their species composition is therefore fortuitous. However, orchard soil can also be covered with specifically selected crop species (24) or the natural flora can be managed by use of adequate herbicide treatment (81). Some plant species used as cover crops or exist-

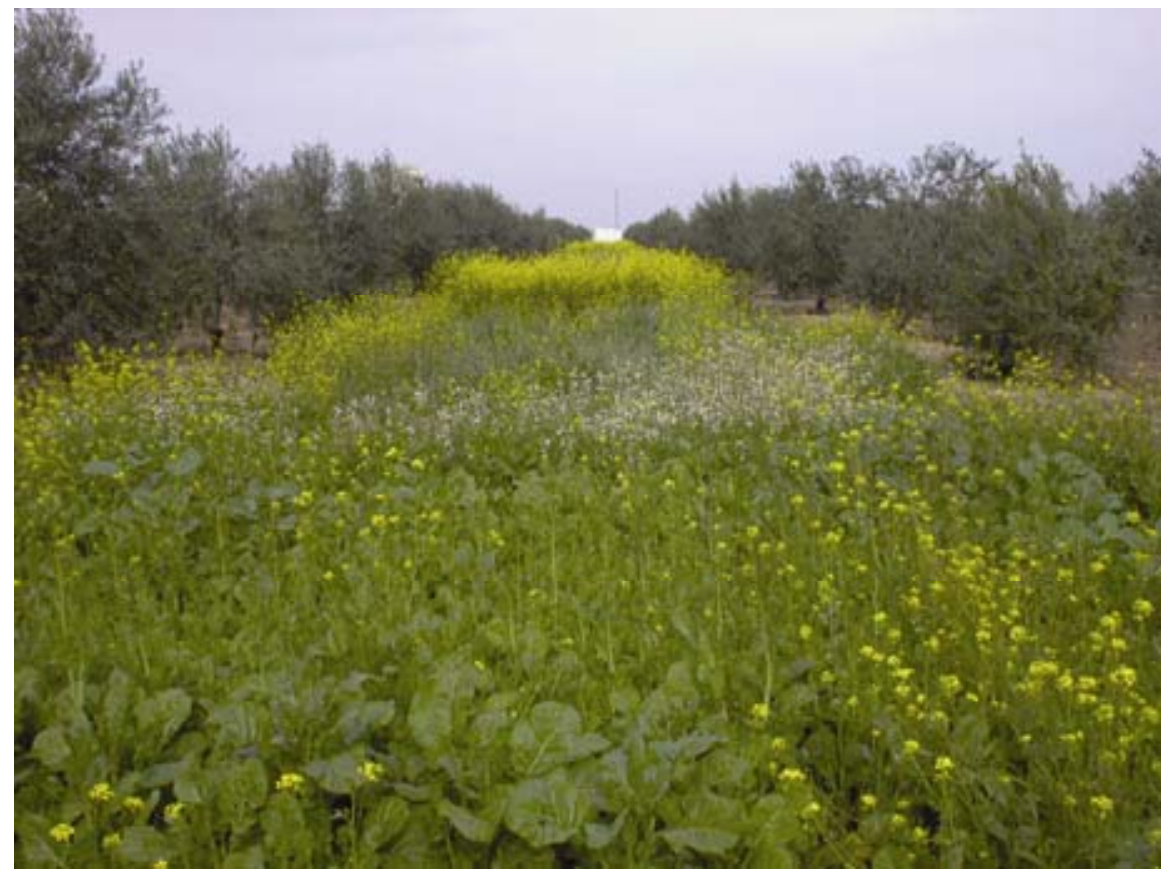

Fig. 14. View of an olive orchard in southern Spain showing different crucifer species used as cover vegetation for preventing soil erosion, improving soil structure and fertility, increasing water infiltration, and reducing surface runoff. ing in natural vegetation (Fig. 14) may be suitable hosts for plant-parasitic nematodes such as Meloidogyne spp. (18,53). Even plants that are poor hosts for the nematode should be limited to soils free of Meloidogyne spp. By displacing native host plants with nonhost or nematicidal species, cover crops could help to reduce numbers of plant-parasitic nematodes in olive orchards, as was demonstrated for other fruit crops (102).

Thermotherapy is a heat-based disinfestation measure used since the nineteenth century to eradicate pests and pathogens from seeds and other propagation stocks (100). This measure was successfully used to produce virus-free fruit-tree planting stocks (66) and Agrobacterium tumefaciens-free grape cuttings (13). Thermotherapy has also been used to eradicate nematodes from infected citrus (39) and grapevine (63) propagation stocks. In order to be successful, the lethal thermal threshold for the nematode must be reached without exceeding the thermal plant tolerance. Studies in our laboratory indicate that the root-lesion nematode $P$. vulnus can survive heat treatments of 25 to $35^{\circ} \mathrm{C}$ regardless of duration, but its viability is severely reduced at 45 to $55^{\circ} \mathrm{C}$ during 1 to 15 min (Fig. 15). However, hot water treatments $\left(35\right.$ to $\left.55^{\circ} \mathrm{C}\right)$ of olive cultivars Arbequina and Picual planting stocks significantly impaired subsequent plant growth unless the planting stocks were pretreated for $10 \mathrm{~min}$ at 30 and $35^{\circ} \mathrm{C}$. Eradication of $P$. vulnus from artificially infected olive planting stocks was achieved by hot water treatment of infected roots at $50^{\circ} \mathrm{C}$ for 2 min, but 40 or $45^{\circ} \mathrm{C}$ during 4 to $20 \mathrm{~min}$ did not significantly affect nematode survival on infected root (M. Teva Fernández, R. M. Jiménez-Díaz, and P. Castillo, unpublished).

\section{Conclusions, Olive Certification Scheme, and Future Prospects}

The removal of many nematicides from the market due to environmental and hu-
A

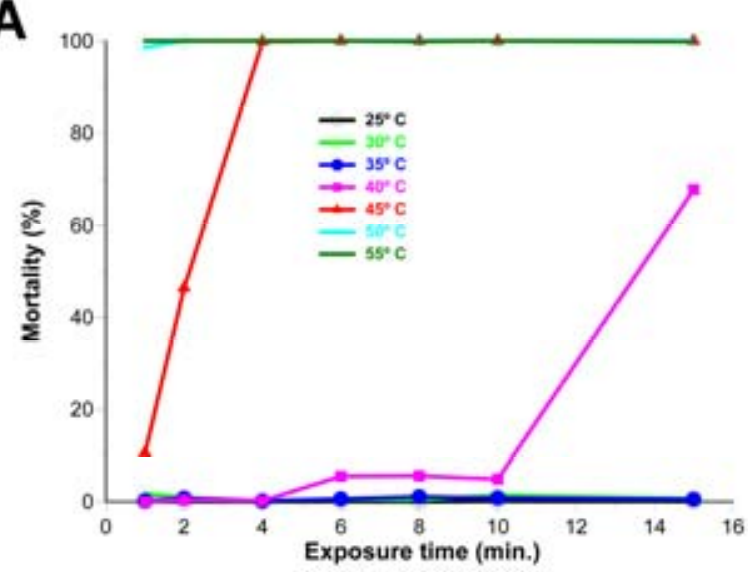

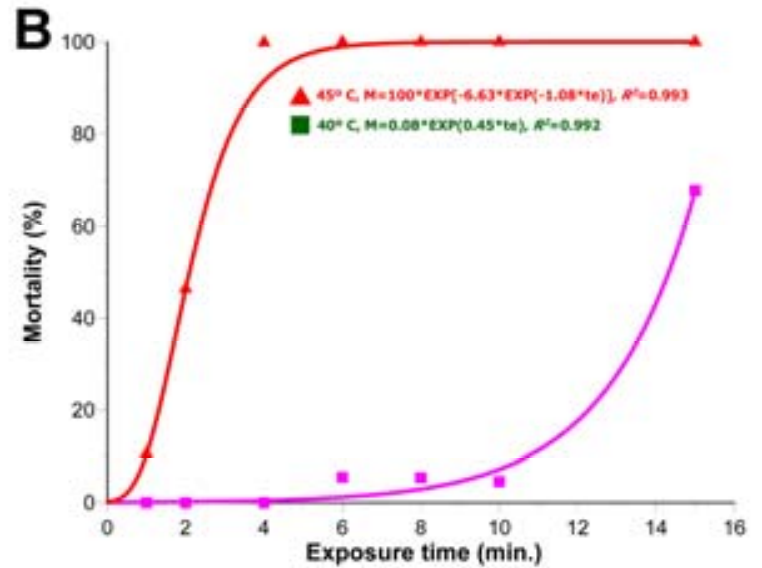

Fig. 15. Effects of in vitro treatment of Pratylenchus vulnus specimens with hot water at 25 to $55^{\circ} \mathrm{C}$ for 1 to 15 min. A, Percent mortality after treatment over time. B, Relationship between nematode mortality (\%) and time of exposure at 40 and $45^{\circ} \mathrm{C}$. 
man health concerns has focused attention on the development of alternative control strategies for managing plant-parasitic nematodes in many crops, including olive. Because few resistant rootstocks have been identified in olive, exclusion should be the first and primary control strategy to consider for management of plant-parasitic nematode in olive orchards. The use of pathogen-free planting material and uninfested soils is essential for minimizing the effects of single or concomitant species of plant-parasitic nematodes and other pathogens during the early years of olive cultivation and for preventing impairment of growth and yield loss. For producing certified olive trees, the rootstocks or scion material (for grafted olive trees) should be grafted or budded only onto rootstocks of equivalent (i.e., propagation-stock) or higher certification status. Plants to be certified should be kept in nursery soil that has been proved free from the nematode species that can cause significant damage to olive growth (e.g., X. diversicaudatum, $M$. arenaria, and $P$. vulnus), and also from all quarantine nematodes (5). Finally, the lack of sufficient levels of nematode resistance or tolerance can be compensated for, to some extent, by the use of other control measures, preferably nonchemical ones, including soil solarization, biofumigation, and biological treatments as we have described. We believe that fulfillment of this strategy would help in maintaining the critical role that olive production plays in Mediterranean farming systems as a major source of oil and fruits, as well as a net contributor to agricultural sustainability in countries with Mediterranean-type climate.

\section{Acknowledgments}

Original results from the authors reported in this article were derived from research supported by grants (AGR-136, AGL2008-00344, and P08-AGR03528) from Dirección General de Investigación, Ministerio de Ciencia e Innovación, Spain and Consejería de Innovación Ciencia y Empresa, Junta de Andalucía, Spain. We would like to express our gratitude to members of the "Plant Health Research Group" AGR-136 for their excellent help and assistance in any part of the research developed.

\section{Literature Cited}

1. Abawi, G. S., and Mai, W. F. 1975. Effect of foliar applications of oxamyl on movement of Pratylenchus penetrans in and outside host roots. Plant Dis. Rep. 59:795-799.

2. Abrantes, I. M. de O., Vovlas, N., and Santos, M. S. N. 1992. Host-parasite relationships of Meloidogyne javanica and M. lusitanica with Olea europaea. Nematologica 38:320-327.

3. Akhtar, M., and Alam, M. M. 1993. Utilization of waste materials in nematode control: A review. Biores. Technol. 45:1-7.

4. Al-Sayed, A., and Abdel-Hameed, S. H. 1991. Resistance and susceptibility of olives to Meloidogyne incognita and Rotylenchulus reniformis. Ann. Agric. Sci. Moshtohor 29:1221-1226.

5. Anonymous. 2006. Schemes for the production of healthy plants for planting. Pathogentested olive trees and rootstocks. EPPO Bull. 36:77-83.

6. Australian Pesticides and Veterinary Medi- cines Authority (APVMA). 2009. APVMA PUBCRIS database. http://services.apvma. gov.au/PubcrisWebClient/welcome.do.

7. Azcón-Aguilar, C., and Barea, J. M. 1996. Arbuscular mycorrhizas and biological control of soil-borne plant pathogens - An overview of the mechanisms involved. Mycorrhiza 6:457-564.

8. Baldwin, J. G., and Mundo-Ocampo, M. 1991. Heteroderinae, cyst and non cyst-forming nematodes. Pages 275-362 in: Manual of Agricultural Nematology. W. R. Nickle, ed. Marcel Dekker, Inc., New York.

9. BOE. 1999. Modificación del reglamento técnico de control y certificación de plantas de vivero de frutales. Boletín Oficial Estado 276:40077-40079.

10. BOJA. 1997. Reglamento específico de producción integrada del olivar. Boletín Junta Andalucía 100:10543-10555.

11. Bravo, M., and Roca, F. 1997. Two Longidorus species (Nematoda: Longidoridae) occurring in the rhizosphere of olive trees in northeastern Portugal. Agron. Lusitana 46:101-121.

12. Brzeski, M. W., Hánel, L., Nico, A. I., and Castillo, P. 1999. Paratylenchinae: Redescription of Paratylenchus arculatus Luc \& de Guiran, 1962, a new senior synonym of $P$. nainianus Edward \& Misra, 1963 (Nematoda: Tylenchulidae). Nematology 1:375-380.

13. Burr, T. J., Ophel, K., Katz, B. H., and Kerr, A. 1989. Effect of water treatment on systemic Agrobacterium tumefaciens biovar 3 in dormant grape cuttings. Plant Dis. 73:242245.

14. CASAFE. 2009. Guía de Productos Fitosanitarios. Tomo I: generalidades e insecticidas. Cámara de Sanidad Agropecuaria y Fertilizantes, Buenos Aires, Argentina.

15. Castellanos, S., Linardelli, C., Tarquini, A., Lafi, J., Puglia, C., del Toro, M. S., Echevarría S., and Bustamante, C. 2005. Estudio de la interacción Meloidogyne-Fusarium en plantas de olivo de los cvs. Manzanilla y Frantoio en invernadero en Mendoza, Argentina. Nematropica 35:64-65.

16. Castillo, P., Navas-Cortes, J. A., Landa, B. B., Jimenez-Diaz, R. M., and Vovlas, N. 2008. Plant-parasitic nematodes attacking chickpea and their in planta interactions with rhizobia and phytopathogenic fungi. Plant Dis. 92:840-853.

17. Castillo, P., Nico, A. I., Azcón Aguilar, C., Del Río Rincón, C., Calvet, C., and JiménezDíaz, R. M. 2006. Protection of olive planting stocks against parasitism of root-knot nematodes by arbuscular mycorrhizal fungi. Plant Pathol. 55:705-713.

18. Castillo, P., Rapoport, H. F., Palomares-Rius, J. E., and Jiménez-Díaz, R. M. 2008. Suitability of weeds species prevailing in Spanish vineyards as hosts for root-knot nematodes. Eur. J. Plant Pathol. 120:43-51

19. Castillo, P., and Vovlas, N. 2002. Factors affecting egg hatch of Heterodera mediterranea and differential responses of olive cultivars to infestation. J. Nematol. 34:146-150.

20. Castillo, P., and Vovlas, N. 2007. Pratylenchus (Nematoda: Pratylenchidae): Diagnosis, Biology, Pathogenicity and Management. Brill, Leiden, Netherlands.

21. Castillo, P., Vovlas, N., Nico, A. I., and Jiménez-Díaz, R. M. 1999. Infection of olive trees by Heterodera mediterranea in orchards in southern Spain. Plant Dis. 83:710-713.

22. Castillo, P., Vovlas, N., Subbotin, S., and Troccoli, A. 2003. A new root-knot nematode, Meloidogyne baetica $\mathrm{n}$. sp. (Nematoda: Heteroderidae), parasitizing wild olive in southern Spain. Phytopathology 93:1093-1102.

23. Castillo, P., Vovlas, N., and Troccoli, A. 2003. The reniform nematode, Rotylenchulus macrosoma, infecting olive in southern Spain.
Nematology 5:23-29.

24. Castro, J. 1993. Control de la erosión en cultivos leñosos con cubiertas vegetales vivas. $\mathrm{Ph} . \mathrm{D}$. thesis. University of Córdoba, Córdoba, Spain.

25. D'Addabbo, T. 1995. The nematicidal effect of organic amendments: A review of the literature: 1982:1994. Nematol. Mediterr. 23:299-305.

26. Diab, K. A., and El-Eraki, S. 1968. Plant parasitic nematodes associated with olive decline in the United Arab Republic. Plant Dis. Rep. 52:150-154.

27. DOCM. 2003. Orden de 19-03-2003 de la Consejería de Agricultura y Medio Ambiente, por la que se regula la presentación, concesión y gestión de ayudas a los planes de reestructuración y/o reconversión del viñedo de Castilla-La Mancha. Diario Oficial de Castilla-La Mancha 49:5258-5263.

28. Doucet, M. E., Ponce de León, E. L., and Poloni, N. 1997. Alteraciones histológicas inducidas por Meloidogyne incognita en raíces de olivo en Catamarca, Argentina. Nematol. Mediterr. 25:275-277.

29. El-Borai, F. E., and Duncan, L. W. 2005. Nematode parasites of subtropical and tropical fruit tree crops. Pages 469-492 in: Plant Parasitic Nematodes in Subtropical and Tropical Agriculture. M. Luc, R. A. Sikora, and J. Bridge, eds. CABI Publishing, Wallingford, UK.

30. EPPO/OEPP 1993. Certification schemes. No. 7. Nursery requirements-recommended requirements for establishments participating in certification of fruit or ornamental crops. Bull. OEPP/EPPO Bull. 23:249-252.

31. EPPO/OEPP. 2008. EPPO Standard. EPPO $\mathrm{A} 1$ and $\mathrm{A} 2$ lists of pests recommended for regulation as quarantine pests. Phytosanitary Measure 1-2 (17). European and Mediterranean Plant Protection Organization, Paris

32. Esbenshade, P. R., and Triantaphyllou, A. C. 1985. Use of enzyme phenotypes for identification of Meloidogyne (Nematoda: Tylenchida). J. Nematol. 17:6-20.

33. Feinbrun-Dothan, N. 1978. Flora Palaestina. Vol. 3. Jerusalem Israel Academy of Science and Humanities. pp. 14-15

34. Food and Agriculture Organization of the United Nations Statistical Database (FAOSTAT) 2007. FAOSTAT production statistics of crops. Online database. http://faostat.fao.org/

35. Hogue, E. J., and Neilsen, G. H. 1987. Orchard floor vegetation management. Hortic. Rev. 9:377-430.

36. Inserra, R. N., and Vovlas, N. 1977. Parasitic habits of Gracilacus peratica on olive feeder roots. Nematol. Mediterr. 5:345-348.

37. Inserra, R. N., Vovlas, N., and Morgan Golden, A. 1979. Helicotylenchus oleae n. sp. and $H$. neopaxilli n. sp. (Hoplolaimidae), two new spiral nematodes parasitic on olive trees in Italy. J. Nematol. 11:56-62.

38. Jiménez, R. M., Gallo, D. P., and Sotomayor, L. E. 2002. Experimental control of Tylenchulus semipenetrans Cobb. affecting olive-tree crop. IDESIA. 20:91-102.

39. Kaplan, D. T. 1982. Erradication of Pratylenchus coffeae in "Carrizo" citrange seedlings. Proc. Fla. State Hortic. Soc. 95:70-72.

40. Karssen, G., and Moens, M. 2006. Root-knot nematodes. Pages 59-90 in: Plant Nematology. R. N. Perry and M. Moens, eds. CABI, Wallingford, UK.

41. Katan, J. 1981. Solar heating (solarization) of soil for control of soilborne pests. Annu. Rev. Phytopathol. 19:211-236.

42. Kepenekci, I. 2001. Preliminary list of Tylenchida (Nematoda) associated with olive in the Black Sea and the Mediterranean regions of Turkey. Nematol. Mediterr. 29:145-147.

43. Kierkegaard, J. A., Gardner, P. A., Desmarchelier, J. M., and Angus, J. F. 1993. Bio- 
fumigation: Using Brassica species to control pests and diseases in horticulture and agriculture. Pages 77-82 in: 9th Australian Research Assembly on Brassicas. N. Wratten and R. J. Mailer, eds. Agricultural Research Institute, Wagga Wagga, Australia.

44. Koenning, S. R., Overstreet, C., Noling, J. W., Donald, P. A., Becker, J. O., and Fortnum, B. A. 1999. Survey of crop losses in response to phytoparasitic nematodes in the United States for 1994. J. Nematol. 31:587-618.

45. Lamberti, F., and Baines, R. C. 1969. Pathogenicity of four species of Meloidogyne on three varieties of olive trees. J. Nematol. 1:111-115.

46. Lamberti, F., and Baines, R. C. 1969. Effect of Pratylenchus vulnus on the growth of "Ascolano" and "Manzanillo" olive trees in a glasshouse. Plant Dis. Rep. 53:557-558.

47. Lamberti, F., Ciccarese, F., Sasanelli, N., Ambrico, A., D'Addabbo, T., and Schiavone, D. 2001. Relationships between plant parasitic nematodes and Verticillium dahliae on olive. Nematol. Mediterr. 29:3-9.

48. Lamberti, F., and Di Vito, M. 1972. Sanitation of root-knot nematode infected olive-stocks. Pages 401-411 in: Actas III Congr. Uniao Fitopatol. Mediterr. Oeiras, Portugal.

49. Lamberti, F., Sasanelli, N., D'Addabbo, T., Ciccarese, F., Ambrico, A., and Schiavone, D. 2002. Relationship between plant parasitic nematodes and Verticillium dahliae in olive. Acta Hortic. 586:749-752.

50. Lamberti, F., Vouyoukalou, E., and Agostinelli, A. 1996. Longidorids (Nematoda: Dorylaimoidea) occurring in the rhizosphere of olive trees in Western Crete, Greece. Nematol. Mediterr. 24:79-85.

51. Lamberti, F., and Vovlas, N. 1993. Plant parasitic nematodes associated with olive. Bull. OEPP/EPPO 23:481-488.

52. Lamberti, F., Vovlas, N., and Tirro, A. 1976. Infettivita e patogenicita de tre popolazioni italiane di Tylenchulus semipenetrans su agrumi ed altri ospidi. Nematol. Mediterr. 4:85-91.

53. Liébanas, G., and Castillo, P. 2004. Host suitability of some crucifers for root-knot nematodes in southern Spain. Nematology 6:125128.

54. Liphschitz, N., Gophna, R., Hartman, M., and Biger, G. 1991. The beginning of olive (Olea europaea) cultivation in the old world: A reassessment. J. Arch. Sci. 18:441-453.

55. López-Escudero, F. J., and Blanco-López, M. A. 2001. Effect of a single or double soil solarization to control Verticillium wilt in established olive orchards in Spain. Plant Dis. 85:489-496.

56. Lorrain, R. 1998. Moyens de contrôle du risque nématologique. L'arboric. Fruit. 514:37-41.

57. Marte, M., Gadani, F., Savino, V., and Rugini, E. 1986. Strawberry latent rings pot virus associated with a new disease of olive in Central Italy. Plant Dis. 70:171-172.

58. Martelli, G., and Taylor, C. E. 1989. Distribution of viruses and their nematode vectors. Pages 151-189 in: Advances in Disease Vector Research. G. Martelli, ed. Springer-Verlag, New York.

59. McKenry, M. V. 1994. Nematodes of Olive. Pages 97-99 in: Olive Production Manual. L. Ferguson, G. S. Sibett, and G. C. Martin, eds. University of California, Oakland, Publ. 3353.

60. Ministerio de Agricultura, Servicio Agrícola y Ganadero. 2007. Regulaciones para la importación de material de reproducción de olivo (Olea europaea subsp. europaea) procedente de los estados miembros de la Comunidad Europea. No. 2425.

61. Ministerio de Medio Ambiente y Medio Rural y Marino (MARM). 2009. Registro de Pro- ductos Fitosanitarios.http://www.mapa.es/es/ agricultura/pags/fitos/registro/menu.asp

62. Ministero delle politiche agricole, alimentari e forestali. 2009. Fitofarmaci e Sostanze Attive. http://www.sian.it/fitovis/

63. Nandini, G., and Mathur, V. K. 1995. Erradication of root-knot nematodes from grapevine rootstocks by thermal therapy. Nematologica 41:269-271.

64. Navas, A., Bello, A., and Arias, M. 1988. Ecology and potential distribution of Xiphinema diversicaudatum and $X$. pachtaicum (Nematoda: Longidoridae) in continental Spain. Nematologica 34:314-330.

65. Nejad, S. A. H., Maafi, Z. T., and Barooti, S. 1997. Nematodes associated with olive trees (Olea europaea L.) in Iran. Appl. Entomol. Phytopathol. 65:10-12.

66. Nemeth, M. 1986. Control of fruit tree virus diseases. Pages 121-144 in: Virus, Mycoplasma and Rickettsia Diseases of Fruit Trees. Forestry Sciences. M. Nijhoff and W. Junk, eds. Akademia Kiado, Publishers, Budapest, Hungary.

67. Nico, A. I., Jiménez-Díaz, R. M., and Casti1lo, P. 2003. Host suitability of the olive cultivars Arbequina and Picual for plant-parasitic nematodes. J. Nematol. 35:29-34.

68. Nico, A. I., Jiménez-Díaz, R. M., and Casti1lo, P. 2003. Solarization of soil in piles for the control of Meloidogyne incognita in olive nurseries in southern Spain. Plant Pathol. 52:770-778

69. Nico, A. I., Jiménez-Díaz, R. M., and Castillo, P. 2004. Control of root-knot nematodes by composted agro-industrial wastes in potting mixtures. Crop Prot. 23:581-587.

70. Nico, A. I., Rapoport, H. F., Jiménez-Díaz, R. M., and Castillo, P. 2002. Incidence and population density of plant-parasitic nematodes associated with olive planting stocks at nurseries in southern Spain. Plant Dis. 86:10751079.

71. O'Bannon, J. H., and Taylor, A. C. 1967. Control of nematodes on Citrus seedlings by chemical bare-root dip. Plant Dis. Rep. 51:995-998.

72. O'Bannon, J. H., and Tomerlin, A. T. 1977. Control of the burrowing nematode, Radopholus similis, with DBCP and oxamyl. Plant Dis. Rep. 61:450-454

73. Peña Santiago, R., Abolafia, J., Liébanas, G., Peralta, M., and Guerrero, P. 2004. Dorylaimid species (Nematoda, Dorylaimida) recorded in the Iberian Peninsula and the Balearic Islands: A Compendium. Servicio de Publicaciones, Universidad de Jaén, Spain.

74. Peña Santiago, R., Castillo, P., Escuer, M., Guerrero, P., Talavera, M., and Vieira, P. 2004. Tylenchid species (Nematoda, Tylenchida) recorded in the Iberian Peninsula and the Balearic Islands: A Compendium. Servicio de Publicaciones, Universidad de Jaén, Spain.

75. Pérez, B. A., Barreto, D., Docampo, D., Otero, L., Costilla, M., Roca, M., and Babbitt, S. 2001. Current status of the drying syndrome (seca) of olive trees in Argentina. (Abstr.) Phytopathology 91:S71.

76. Pinochet, J., Verdejo, S., and Marull, J. 1991. Host suitability of eight Prunus spp. and one Pyrus communis rootstocks to Pratylenchus vulnus, $P$. neglectus, and $P$. thornei. J. Nematol. 23:570-575.

77. Pinochet, J., Verdejo, S., Soler, A., and Canals, J. 1992. Host range of a population of Pratylenchus vulnus in commercial fruit, nut, citrus, and grape rootstocks in Spain. J. Nematol. 24:693-698.

78. Ridolfi, M., Patumi, M., D’Addabbo, T., Sasanelli, N., and Lemos, R. J. 2001. Enzymatic response of olive varieties to parasitism by Xiphinema index (Nematoda: Longidoridae). Russ. J. Nematol. 9:25-32.
79. Rossi, C. E., and Ferraz, L. C. C. B. 2005 Plant-parasitic nematodes of the Superfamily Tylenchoidea associated with subtropical and temperate fruits in the States of São Paulo and Minas Gerais, Brazil. Nematol. Bras. 29:171-182.

80. Rossi, C. E., and Ferraz, L. C. C. B. 2005 Nematodes belonging to Criconematoidea and Dorylaimoidea associated with subtropical and temperate fruits in the States of Sao Paulo and Minas Gerais, Brazil. Nematol. Bras. 29:183-192.

81. Saavedra, M., Garcia-Torres, L., HernandezBermejo, E., and Hidalgo, B. 1990. Influence of environmental factors on the weed flora in crops in the Guadalquivir Valley. Weed Res. 30:363-374.

82. Saeedizadeh, A., Kheiri, A., Okhovvat, S. M., Zad, J., and Nejad, S. A. H. 2006. A study on the growth of one-year-old seedlings of olive cv. Zard in the presence of two different soilborne pathogens, Meloidogyne javanica and Verticillium dahliae. Iran. J. Agric. Sci. 37:793-800.

83. Sasanelli, N., Coiro, M. I., D’Addabbo, T., Lemos, R. J., Ridolfi, M., and Lamberti, F. 1999. Reaction of an olive cultivar and an olive rootstock to Xiphinema index. Nematol. Mediterr. 27:253-256.

84. Sasanelli, N., D’Addabbo, T., Dell'Orco, P., and Mencuccini, M. 2000. The in vitro use of olive explants in screening trials for resistance to the root-knot nematode, Meloidogyne incognita. Nematropica 30:101-106.

85. Sasanelli, N., D'Addabbo, T., and Moura Lemos, R. 2002. Influence of Meloidogyne javanica on growth of olive cuttings in pots. Nematropica 32:59-63.

86. Sasanelli, N., Fontanazza, G., Lamberti, F., D’Addabbo, T., Patumi, M., and Vergari, G. 1997. Reaction of olive cultivars to Meloidogyne species. Nematol. Mediterr. 25:183190.

87. Seinhorst, J. W. 1965. The relationship between nematode density and damage to plants. Nematologica 11:137-154.

88. Shawky, S. M., El-Sawi, M. A. M., and Nabil, Y. M. 2004. Effect of some nematicides on controlling root knot nematodes and determine their residues in olive fruits and soil. Ann. Agric. Sci. (Cairo) 49:389-399.

89. Sobreiro, J., and Reis, C. J. 2008. Guia dos Produtos Fitofarmacêuticos - Condições de Utilização -Insecticidas, Fungicidas e Outros. DGPC, Oeiras, PPA (H/D) 2/99.

90. Stafford, T. R., and Best, L. B. 1999. Bird response to grit and pesticide granule characteristics: Implications for risk assessment and risk reduction. Environ. Toxicol. Chem. 18:722-733.

91. Stukenbrock, E. H., and McDonald, B. A. 2008. The origins of plant pathogens in agroecosystems. Annu. Rev. Phytopathol. 46:75100.

92. Subbotin, S. A., Ragsdale, E. J., Mullens, T. Roberts, P. A., Mundo-Ocampo, M., and Baldwin, J. G. 2008. A phylogenetic framework for root lesion nematodes of the genus Pratylenchus (Nematoda): Evidence from $18 \mathrm{~S}$ and D2-D3 expansion segments of 28S ribosomal RNA genes and morphological characters. Mol. Phylogenet. Evol. 48:491-505.

93. Talavera, M., and Tobar Jimenez, A. 1997. Plant parasitic nematodes from unirrigated fields in Alhama, southeastern Spain. Nematol. Mediterr. 25:73-81.

94. Tjamos, E. C. 1983. Prospects for controlling Verticillium wilt of olive trees by soil solarization. (Abstr.) Page 15 in: Hellenic Congress on Plant Diseases, Athens, Greece.

95. Tzortzakakis, E. A., Peneva, V., Terzakis, M. Neilson, R., and Brown, D. J. F. 2001. Longidorus cretensis n.sp. (Nematoda: Longidoridae) from a vineyard infected with a foliar 
'yellow mosaic' on Crete, Greece. Syst. Parasitol. 48:131-139.

96. Vovlas, N., and Inserra, R. N. 1976. Istopatologia di radici di olivo infestate da Rotylenchulus macrodoratus Dasgupta, Raski et Sher. Nematol. Mediterr. 4:223-230.

97. Vovlas, N., and Inserra, R. N. 1981. Parasitic habits of Ogma rhombosquamatum and description of the male. J. Nematol. 13:87-90.

98. Vovlas, N., and Inserra, R. N. 1983. Biology of Heterodera mediterranea. J. Nematol. 15:571-576.
99. Vovlas, N., Inserra, R., and Lamberti, F. 1975. Risanamento di piantoni di arancio amaro, olivo e vite infestati da nematodi. Pages 271277 in: Atti Giornate Fitopatol. 1975.

100. Waite, H., and Morton, L. 2007. Hot water treatment, trunk diseases and other critical factors in the production of high-quality grapevine planting material. Phytopathol. Mediterr. 46:5-17.

101. Whitehead, A. G. 1998. Plant Nematode Control. CABI, Wallingford, UK.

102. Zehr, E. I., Whittington, D. P., and Scott, J.
M. 1990. Suppression of the nematode Criconemella xenoplax with orchard vegetation. Pages 28-30 in: Proc. Stone Fruit Decline Workshop. Vol 4. University of California, Parlier.

103. Zohary, D., and Spiegel-Roy, P. 1975. Beginnings of fruit growing in the Old World. Science 187:319-327.

104. Zunke, U. 1990. Observations on the invasion and endoparasitic behavior of the root lesion nematode Pratylenchus penetrans. J. Nematol. 22:309-320.

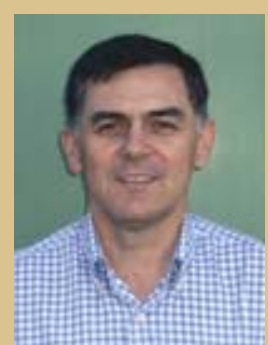

P. Castillo

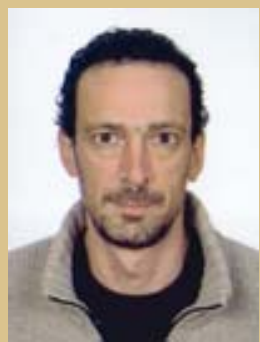

A. I. Nico

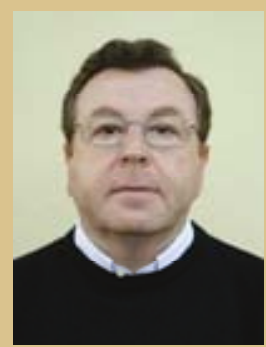

J. A. NavasCortés

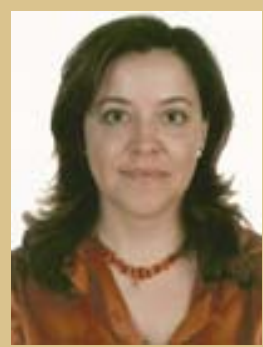

B. B. Landa

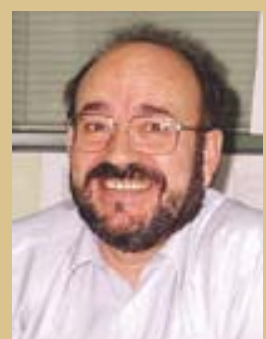

R. M. JiménezDíaz

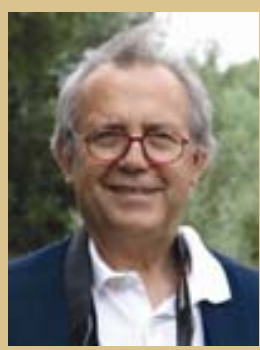

N. Vovlas
Dr. Castillo is a research scientist of nematology at the Institute of Sustainable Agriculture of the Spanish National Research Council at Córdoba, southern Spain. $\mathrm{He}$ received his B.S. (1984) and Ph.D. (1988) from University of Granada (Spain). His research focuses primarily on plant-nematode and nematode-soilborne fungi interactions, as well as diagnosis of nematode diseases, host-parasite relationships, and nematode control by means of strategies compatible with sustainable agriculture. He has contributed to plant nematology with numerous research articles, and he recently coauthored two comprehensive books on the spiral nematode genus Rotylenchus and the root-lesion nematode genus Pratylenchus.

Dr. Nico is a hired researcher at El Chaparrillo Agricultural Center of the Counsil of Agriculture of Castile-La Mancha at Ciudad Real, Spain. He received a B.S. degree in agriculture engineering from University of La Plata (Argentina) and a Ph.D. degree in crop protection from the University of Córdoba (Spain) in 1989 and 2002, respectively. His Ph.D. dissertation dealt with incidence, pathogenicity, and control of plant parasitic nematodes at olive nurseries in Andalusia, southern Spain. His actual research interests focus on ecology and control of soilborne plant pathogens of locally relevant crops.

Dr. Navas-Cortés is a research scientist of plant pathology at the Institute of Sustainable Agriculture, Spanish National Research Council. He received his B.S. degree and Ph.D. degree in biology from the University of Córdoba in 1986 and 1992, respectively. He was a visiting fellow at the Institute of Plant Diseases and Plant Protection, University of Hannover, Germany in 1994 and 1995. His research activity focuses on the ecology of plant pathogenic fungi, and epidemiology and integrated control of plant diseases in sustainable agriculture and impact of climate change on plant pathogens and plant diseases. His main area of expertise is quantitative epidemiology, including modeling and spatio-temporal analysis of plant disease epidemics.

Dr. Landa is a tenured plant pathologist at the Institute of Sustainable Agriculture, Spanish National Research Council. She received a B.S. degree in agriculture engi- neering and a Ph.D. degree in plant pathology from the University of Córdoba in 1995 and 1999, respectively. She was a postdoctoral Fulbright scholar at the USDAARS, Washington State University, Pullman, USA in 2000 and 2001, and research scientist and assistant professor at the University of Córdoba from 2002 to 2007. Her research activity focuses on population biology of soilborne plant pathogens and rhizosphere biocontrol agents, defining the biogeography, genetic diversity, biology, and ecology of phytopathogenic fungi, plant parasitic nematodes, and plant-associated rhizosphere bacteria with potential as biocontrol agents.

Prof. Jiménez-Díaz is a professor of plant pathology at the University of Córdoba with a joint appointment as a research professor at the Institute of Sustainable Agriculture of the Spanish National Research Council. He graduated from the Polytechnic University of Madrid in 1969 and the Department of Plant Pathology, Cornell University in 1976, and was elected a Fellow of the American Phytopathological Society in 1999. He has been head of the Department of Plant Pathology, University of Córdoba, and director of the Institute of Sustainable Agriculture. His research program focuses primarily on the ecology and population biology of soilborne fungi and the integrated management of soilborne diseases, with emphasis on Fusarium wilt and Verticillium wilt diseases.

Prof. Vovlas is research leader at the Istituto per la Protezione delle Piante, C.N.R, Bari, Italy, monographically dedicated to plant nematology. His research interests include nematode taxonomy, biology, and hostparasite relationships. Currently, his responsibilities include teaching nematology, taxonomy, biology, and nematode interactions. He is an active member of the Society of Nematologists, the Organization of Tropical American Nematologists, and the European Society of Nematologists ( $\mathrm{He}$ also served for 4 years as an active member of the governing board of this society.) and currently is on the editorial board of the International Journal of Nematology and Helminthologia. His research activities have resulted in numerous national and international journal articles. He contributed to the CABI Publishing Crop Protection Compendium and recently co-authored two comprehensive monographs. 